Max-Planck-Institut für demografische Forschung

Max Planck Institute for Demographic Research

Konrad-Zuse-Strasse $1 \cdot$ D-18057 Rostock · GERMANY

Tel +49 (0) 3812081 - 0; Fax +49 (0) 3812081 - 202;

http://www.demogr.mpg.de

MPIDR WORKING PAPER WP 2010-025

JUNE 2010 (REVISED DECEMBER 2010)

\title{
A Global Perspective on Happiness and Fertility
}

Rachel Margolis (mlrachel@pop.upenn.edu)

Mikko Myrskylä (myrskyla@demogr.mpg.de)

(C) Copyright is held by the authors.

Working papers of the Max Planck Institute for Demographic Research receive only limited review. Views or opinions expressed in working papers are attributable to the authors and do not necessarily reflect those of the Institute. 
August 26, 2010

\title{
A Global Perspective on Happiness and Fertility
}

\author{
Rachel Margolis ${ }^{1}$ \\ Mikko Myrskylä2
}

\begin{abstract}
The literature on fertility and happiness has neglected comparative analysis. We investigate the fertility-happiness association using data for 86 countries. We find that globally, happiness decreases with the number of children. This association, however, is strongly modified by individual and contextual factors. Most importantly, we find that the association between happiness and fertility evolves from negative to neutral to positive above age 40, and is strongest among those who are likely to benefit most from upward intergenerational transfers. In addition, analyses by welfare regime show that the negative fertility-happiness association for younger adults is weakest in countries with high public support for families, and the positive association above age 40 is strongest in countries where old-age support depends mostly on the family. Overall these results suggest that children are a long-term investment in well-being, and highlight the importance of the life-cycle stage and contextual factors in explaining the happiness-fertility association.
\end{abstract}

Word count, abstract: 150

Word count, main text: 7,849

\footnotetext{
${ }_{1}$ Population Studies Center\& Department and Sociology, University of Pennsylvania, 239 McNeil Building, 3718 Locust Walk, Philadelphia PA 19104. Email mlrachel@pop.upenn.edu. 2 Research Group: Lifecourse Dynamics and Demographic Change, Max Planck Institute for Demographic Research, Konrad-Zuse-Str. 1, 18057 Rostock, Germany. Email myrskyla@demogr.mpg.de.
} 


\section{Introduction}

Much of the world is pervaded by strong cultural beliefs that children increase the wellbeing of parents, and especially women (Baumeister 1991; Blake 1979). These beliefs have bolstered norms about the desirability of having children (McQuillan, Stone, and Greil 2007; Thornton and Young-deMarco 2001), and even though the taboo against childlessness has decreased in much of Europe and North America (Connidis 2001; Park 2002), levels of childlessness have remained low (Kohler, Billari, and Ortega 2002). However, given a few exceptions (Hoffman, Thornton, and Manis 1978; Jones and Brayfield 1997; Kohler, Behrman, and Skytthe 2005), most of the research on parenthood and well-being finds a negative or insignificant relationship between the happiness of parents and their fertility (Cleary and Mechanic 1983; Gore and Mangione 1983; Hakim2000; Lovell-Troy 1983; McLanahan and Adams 1987; Nomaguchi and Milkie 2003). The vast majority of the literature, however, has focused on the U.S. or Northern Europe, ignoring the rest of the world and comparative analysis. This paper investigates the fertility-happiness association globally and across countries using the World Values Surveys data for 86 countries. Our results shed new light on the association between well-being and number of children by showing how the relationship depends strongly on the macro context and life-cycle stage.

Parenthood changes lives in both positive and negative ways, many of them unexpected. Having a child deepens joy, strengthens social ties with family and friends (Gallagher and Gerstel 2001; Umberson and Gove 1989) and creates a new role for adults which carries rights, responsibilities, and a sense of adulthood (Sieber 1974; Hoffman and Manis 1982). However, becoming a parent also increases housework (Sanchez and Thomson 1997), decreases relationship quality between parents (Crohan 1996; Lavee, Sharlin and Katz 1996), and strains 
psychological well-being (McLanahan and Adams 1987; Ross, Mirowsky and Goldsteen 1990; Umberson and Williams 1999).

The relative importance of these countervailing forces may depend on the institutional context and individual level factors. However, the relationship between subjective well-being and childbearing has been understudied, especially in the light of its potential to explain demographic behavior in a time when fertility is a choice for most people in the world (Hobcraft 2006). While some analyses suggest that the fertility differences across Europe could be partially explained by the compatibility between subjective well-being and the number of children (Billari 2008), there are no global, comparative analyses of the happiness-fertility association. Such a global and comparative examination of the fertility-happiness association may inform us about the determinants of fertility in a world that is characterized by unprecedented differences in fertility levels, ranging from less than one child to more than seven children per woman (World Bank 2010). In addition, more research is needed on the individual determinants of the happiness-fertility link, as several theories predict that individual factors importantly influence the association, but relatively little empirical work has been done to study the importance of these factors.

This paper focuses on the association between fertility and subjective well-being globally and across contexts, and analyzes how individual level factors modify the relationship. We draw on research from sociology, psychology, and economics which suggests that the association between fertility and happiness differs for population subgroups, at different stages of the life cycle, and in different contexts.

First, the relationship between fertility and happiness may vary by gender and marital status. Women and men experience the transition to parenthood differently (Cowan et al. 1985; 
LaRossa and LaRossa 1981), with women experiencing greater stress and stronger negative shocks in well-being (Nomaguchi and Milkie 2003; Scott and Alwin 1989; Simon 1992). This may be because women are more often the primary caregiver (Ross and VanWilligen 1996), experience greater work family conflict (Goldsteen and Ross 1989), or have less leisure time (LaRossa and LaRossa 1981). Similarly, the unmarried may experience more strain from childbearing than the married (Nomaguchi and Milkie 2003; Umberson and Williams 1999). Both unmarried mothers and fathers report higher levels of distress than the married in the U.S. which may be due to higher levels of distress, fewer coping resources, or distress caused by being a non-resident parent (Nomaguchi and Milkie 2003).

Second, the relationship between fertility and happiness may change throughout the life cycle. For example, research in North America found that among those in childbearing years, those with children have higher levels of distress than non-parents (Cleary and Mechanic 1983; Gore and Mangione 1983; Lovell-Troy 1983; McLanahan and Adams 1987), however among the elderly, there is no relationship between parenthood and well-being (Connidis and McMullin 1993; Koropeckyj-Cox, Pienta, and Brown2007; Rempel 1985; Ross and Huber 1985). This may be due to the financial and emotional costs of rearing children which are greatest when children are young. However, later in the life course, when parents are elderly, children may provide needed care to parents in poor health or act as insurance or social protection in old age if those institutions are weak, for example in developing countries (Caldwell 1978).

Third, the relationship between fertility and well-being may vary according to institutional and cultural context (Mirowsky and Ross 2003). Research focusing on North America has found either a negative or insignificant relationship between parenthood and wellbeing (Cleary and Mechanic 1983; Connidis and McMullin 1993; Gore and Mangione 1983; 
Koropeckyj-Cox, Pienta, and Brown 2007; Lovell-Troy 1983; McLanahan and Adams 1987;

Rempel 1985). However, studies using European data find either no differences between parents and non-parents (Bergman and Daukantaite, 2006; Hansen, Slagsvold, and Moum 2009; Savolainen et al. 2001) or a weak positive relationship between children, especially the first child, and life satisfaction (Daukantaite and Zukauskiene 2006; Dykstra and Wagner 2007; Kohler et al. 2005). Hansen and colleagues (2009) interpret the fact that parenthood is either unrelated to or positively related to well-being in Northwest Europe because the welfare state equalizes the costs of raising children and eases the combination of parenthood, marriage and work.Similarly, Aassve and colleagues (2008) find that among European countries, parents in social democratic countries are happier than parents in countries with conservative or liberal welfare regimes. As the relationship between fertility and well-being is theorized to vary according to institutional and cultural context, our understanding of the topic will benefit from a global and cross-national perspective. However to date, little research on happiness and fertility has been done in comparative perspective and outside of Europe and North America.

Our article examines the relationship between the subjective well-being of parents and fertility cross-nationally and tests various mechanisms through which well-being and the number of children may be related. We first examine how the relationship between subjective well-being and number of children varies globally. Then we examine how the relationship between happiness and fertility varies on seven key dimensions- five at the individual level and two at the contextual level.We consider the demographic characteristics of age, sex, and partnership status, and two measures of well-being, relative income and health status. Last, we examine how the relationship between subjective well-being and number of children differs for countries in different welfare regimes and in different phases of the fertility transition. Our study contributes 
to the literature on well-being and fertility by providing, to our knowledge, the first global overview on how childbearing and well-being are related. We also show how this relationship is modified by individual and contextual factors. Compared to prior research, our study has the additional strength of having a very rich and large data set which allows us to test various mechanisms by stratification while controlling for potentially important moderating factors such as socioeconomic status, partnership status, and health.

\section{Data}

We use the World Values Surveys (WVS) to examine the relationship between subjective well-being and fertility, globally and cross-nationally. The WVS assesses the state of socio-

cultural, moral, and political values through a series of questionnaires implemented with face-toface interviews. It is the largest international survey that includes questions on life satisfaction and happiness. In this analysis, we use survey waves conducted between 1981 and 2005 and respondents aged 15 and above at the time of the interview.Of the 328,449 respondents, we exclude 126,461 respondents because of missing data for key variables or differences in the country questionnaires omitting questions of interest. This leaves us 201,988 respondents from 86 countries or regions (Germany is broken into its former East and West boundaries). The samples in developed countries are often close to representative, however samples from developing countries are not random (Inglehart et al. 2000).

\section{Dependent Variable}

The dependent variable is the respondent's level of happiness about his or her life. Respondents were asked, "Taking all things together, would you say you are very happy, quite 
happy, somewhat happy or not at all happy?" We treat happiness as a continuous variable with observed range from one (not happy at all) to four (very happy). Although cross-national comparisons in happiness are relatively standard (Cantril1965; Deaton 2008; Diener, Helliwell, and Kahneman 2010), the validity of these comparisons may be questionable as people from different backgrounds, languages, and cultures may use different scales in reporting happiness, despite the best efforts to frame the questions to be culture- and context-sensitive. Thus differences in observed happiness levels may be at least partially due to differences in reporting and partially due to real differences in well-being (Borooah 2006). Therefore, in our analysis of the relationship between number of children and happiness, we always control for the countyspecific overall level of happiness and the year of interview. This effectively removes the problem of country-specific differences in observed happiness levels, be they due to reporting differences or true differences in well-being. The assumption that we make is that the observed differences in the relationship between happiness and number of children across countries and contexts reflect true differences in the relationship, not differences in reporting practices. For this assumption to hold we only need to believe that the number of children does not influence the way happiness is being reported within countries although it may influence the level of happiness, which interests us. This is a markedly weaker assumption and more likely to hold.

\section{Key Explanatory Variable}

Our key explanatory variable is the number of children that the respondent has. Respondents were asked, "Have you had any children?" We code the number of children as: none, one, two, three, or four or more. 


\section{Other Independent Variables}

We explore how the fertility/happiness relationship varies with the demographic factors of age, sex, and marital status. Respondents' age at interview was reported in years and we code age as: $15-19,20-29,30-39,40-49$, and 50 and above. When conducting analysis on subpopulations when sample sizes are smaller, we collapse age groups to 15-19, 20-39, and 40 and above. Thus, our analysis is based on a synthetic cohort, constructed from cross-sectional data, rather than a true cohort using longitudinal data. Marital status is coded as whether the respondent is single, married, living as married, separated or divorced, or widowed. Occasionally, we combine marital status groups to a two category variable coded as partnered (married or living as married) or not partnered (single, separated or divorced, widowed) to increase statistical power. We also examine the individuals' subjective state of health. Respondents were asked, "All in all, how would you describe your state of health these days?" We code responses as either good/very good or fair/poor/very poor.

We use two measures of socioeconomic status. The first is relative household income level. Respondents were shown a card representing a scale of incomes ranging from 1 "lowest income decile" to 10, the "highest income decile". Respondents were asked in which group their household was, "including all wages, salaries, pensions and other incomes that come in." We code relative household income into three groups: low (deciles 1-4), medium (deciles 5-6), and high (deciles $7-10^{1}$ ). Our second measure of socioeconomic status is self-reported social class. respondents were read "People sometimes describe themselves as belonging to the working class, the middle class, or the upper or lower class. Would you describe yourself as belonging to the: upper class, upper middle class, lower middle class, working class, or lower class?" We code socioeconomic status as: low (working or lower class), middle (middle and lower middle), or 
high (upper middle or upper class). We focus on relative income and social class instead of educational attainment since the former are relative measures within each country and thus comparable across countries, whereas the latter depends more on the country's overall educational level than on the individual's characteristics, decreasing validity in cross-country comparisons. Moreover, relative status within a society seems to matter more for subjective wellbeing than the overall income level of the country (Easterlin 1995).

We also examine two contextual level variables- welfare regime and stage of fertility decline. Welfare regime is an extended categorization of Esping-Andersen's typology (1990), which describes the ways in which welfare production is allocated between the state, the market, and households. Social democratic states are the Nordic countries which are committed to comprehensive risk coverage, generous benefits, and egalitarianism, conservative states are those of continental Europe which blend public and familial support, and liberal states are the Anglophone countries which promote market solutions to individual risks. We add countries to his social democratic, conservative, and liberal welfare regimes that fit his criteria and create three additional categories: southern Europe, former socialist countries, and developing nations. The list of countries in each welfare regime is included in Table A1 in the Appendix.We examine the stage of fertility decline of each country by coding the total fertility rate (TFR) for each country and survey year into categories. The source for TFR is the World Bank Development Indicators Database (World Bank 2010), with the following exceptions. Data for Taiwan, East and West Germany, and Andorra were not available from this database. We gathered these fertility data from Lee (2009) for Taiwan, Lechner (2001) for East and West Germany, and from the CIA World Fact Book (2010) for Andorra. The TFR for each country and survey year is shown in Table A2 in the Appendix. We use linear interpolation to fill in the 
TFR for years in which it is missing, using data from prior and later years. We construct a categorical fertility variable for the fertility of the country in that period. It is coded as: lowest low (TFR $<1.3$ ), low (TFR 1.3-2), moderate (TFR 2-3), high (TFR $\geq 3$ ).

\section{Methods}

We use linear regression models to estimate the association between number of children and happiness. ${ }^{2} \mathrm{We}$ estimate the association using global models which use all the data, and stratified models which focus on specific individual and contextual variables. Global Model 1 estimates the association between happiness and number of children while controlling for only age, sex, country, and year of interview. In order to see how potentially important confounders affect the global relationship between happiness and fertility, we estimate Model 2, which adds controls for marital status, relative income, and socioeconomic status. Next, we examine how the relationship between fertility and happiness varies on seven key dimensions. We estimate models stratified by three demographic characteristics of the respondent (age, sex, and partnership status) two measures of well-being (relative income and health status); and two contextual variables (welfare regime and stage of fertility transition).

We chart the coefficients for the number of children by these key variables in Figures 18. On each chart, statistical significance from zero is noted with squares or circles on each point. However, our figures allow much more than a comparison between parity zero and higher parities. As the coefficients are based on linear regression models, it is straightforward to change the reference group while reading the graphs. In particular, for any regression model that is charted in the graphs, the difference between any two regression coefficients represents the happiness difference between the respective parities. This allows comparing the happiness levels 
between any two parities, not just between parity zero and higher parities. For example, one can compare those with two children to those with one child, or those with three children to those with two. Such comparisons are conducted in the discussion of the results.

\section{Results}

Sample characteristics in Table 1 reveal large contextual differences in happiness and number of children in our analytic sample. In the table, we rank countries according to the mean level of happiness. Tanzania, El Salvador, and Venezuela rank highest in happiness, with mean happiness above 3.4 in these countries. Moldova, Belarus, and Albania rank the lowest, with mean happiness below 2.5. The number of children respondents have at the time of the survey also varies between countries, from the Dominican Republic, Andorra, and Ethiopia under 1.20 to Jordan with 3.09. ${ }^{3}$ As the countries sampled have different age distributions, the mean age of each country's sample varies from 28.8 in the Dominican Republic to almost 50 in Switzerland. Similarly, there are large differences in the proportions married. Although less than twenty percent of respondents in Indonesia were married, more than 85 percent were married in China.

\section{TABLE 1 ABOUT HERE}

\section{Global Results}

First, we examine the relationship between subjective well-being and number of children globally. Tables 2 and 3 present coefficients for linear regression models predicting the level of reported happiness among all respondents in all countries in the analytic sample. We show results from two models. Model 1 estimates the association between number of children and happiness, controlling for age, sex, country, and year. Model 2 includes all the variables from Model 1 and also income, socioeconomic status, and marital status. The coefficients for the 
number of children (one, two, three, four or more) are estimated in reference to those with no children. $^{4}$

\section{TABLES 2 AND 3 ABOUT HERE}

The results from Model 1 suggest that compared to those with no children, those with one, two, or three children have significantly higher reported happiness. At parity four and above, there is no significant difference in reported happiness from those with no children. In Model 2, we add controls for marital status, income, and socioeconomic status, which are all related to both fertility and happiness. Including these confounders yields different associations between fertility and happiness than those found in Model 1. Results from Model 2 show that having one, two, three, or four or more children is associated with significantly lower reported happiness than those who are childless, after controlling for potentially important confounders. Having one or two children is associated with 0.03 unit decrease in happiness $(p<0.001)$, and having 4 or more children is associated with even larger decrease in happiness (0.06 units; comparison to 1 or 2 children: $\mathrm{p}<0.05$ ). As Model 2 better controls for the potentially confounding variables of marital status and socioeconomic position than Model 1, our results suggest that globally, having children is associated with decreased happiness. The size of the coefficients may seem small, in that they are about $5 \%$ and $8 \%$ of a standard deviation in happiness. However they are comparable in magnitude to associations between happiness and other better studied variables. For example, the difference in happiness between those with zero children and those with one or two children ( 0.03 units) is similar to women compared to men (0.03), and the happiness difference between childless and those with 4 children (0.06) is similar to the difference in happiness between middle and high income respondents $(0.05)$. 
Results by Age, Sex, and Partnership Status

Next we explore how the relationship between subjective well-being and number of children varies by demographic factors- age, sex, and partnership status. Both happiness and number of children vary throughout the life course with age. Moreover, the relationship between happiness and number of children may depend on age because the way in which the nature and demands of parenthood change as children develop. Figure 1 plots coefficients from linear regression models for the number of children, estimated separately for the respondents' age group (15-19, 20-29, 30-39, 40-49, 50 and above). The results indicate that the association between number of children and happiness strongly depends on age. In the youngest age groups (less than 30), happiness decreases approximately monotonically with number of children. At ages 30-39, the negative association vanishes, and at older ages (40-49, 50 and above) the association of number of children and happiness changes to positive so that those with three children are happiest.

\section{FIGURES 1 AND 2 ABOUT HERE}

The observed age gradient in the happiness-fertility link in Figure 1 could indicate that the effect of having children changes as people and their children age, or it could signal cohort or period differences in happiness-fertility link. To study this, we estimated the happiness-fertility association for two periods, 1981-1996 and 1997-2007, which divides our sample into two parts. Comparing the age gradient for these two time periods allows us to analyze whether the aging or cohort explanation is more accurate. Figure 2 shows that although there is weak evidence of the happiness-fertility relationship being marginally different for the two time periods, we still observe a strong and similar age gradient in the happiness-fertility link for both periods. This result does not support the idea that the age gradient is an artifact of cohort or period differences, 
but is consistent with the aging explanation for the gradient in the happiness-fertility association. Given the strong age gradient in the happiness-fertility link, in all our further analyses we stratify the results by age.

\section{FIGURES 3 AND 4 ABOUT HERE}

We next explore whether there are sex differences in the relationship between happiness and children. To retain large sample sizes we have collapsed age categories to 15-19, 20-39, and 40 and above. We do not present results for parity three or more for the 15-19 age group because of the small sample size. Figure 3 shows that negative association of having children and happiness at ages 20-39 does not differ markedly by sex. At older ages, the positive association between children and happiness is slightly stronger for women than for men, although not statistically significantly.

We next turn to whether the relationship between children and happiness varies by partnership status. Figure 4 shows the happiness-fertility relationship by age and partnership status. We observe that within each age group, the happiness-fertility association is remarkably similar between those who are partnered and not partnered. ${ }^{5}$ Further analyses (results not shown) indicate that this is also true when stratifying by sex.

\section{Results by Economic Well-Being and Health Status}

Next we analyze how the fertility-happiness relationship varies by economic well-being and health status. Figures $5 \mathrm{a}-5 \mathrm{c}$ show the association between fertility and happiness by age and income group. Figures 5a and 5b, which show the results for 15-19 and 20-39 year age groups, indicate that while the income differences are small, the negative association between happiness and fertility is strongest among those with fewer financial resources, and weakest among those 
with best financial resources (Ages 20-39 Parity 4, p<0.01). A high income may help alleviate the burden of raising children, for example through paid childcare. A high income may also be a proxy for postponement. In this case, the high income group would include more people who in their 30 s are still voluntarily in parity 0 or 1 , whereas among the low income group low parity may signal infertility or problems finding a partner. However, at ages 40 and above (Figure 5c), where the associations between happiness and fertility is positive, there are no differences between income groups.

FIGURES 5A, 5B AND 5C ABOUT HERE

We next turn to the health status of respondents, shown in Figure 6. We have categorized health status as good/very good and fair/poor/very poor. The results do not suggest any strong differences in the happiness-fertility link by health. In both health groups, we observe a similar age gradient. The largest difference is in the magnitude of the positive happiness-fertility relationship at ages above 40 between those in good or poor health. The finding that the association is stronger for those in poor health could indicate that children provide care for their ill parents. Among the healthy this care is not needed, thus the association between having children and happiness is weaker.

\section{FIGURE 6 ABOUT HERE}

\section{Analysis by Welfare Regime}

Our next research question asks whether the relationship between subjective well-being and number of children varies by type of welfare regime, where the public support for parenthood differs. We hypothesized that during prime childbearing years, the relationship between fertility and happiness would be less negative in the social democratic and conservative 
states which provide the greatest support for childbearing. We also hypothesized that people with children at older ages would be much happier than those without children in places with weak welfare states such as developing nations because children often act as insurance for old age.

Figure 7a shows the association between fertility and happiness for the age group 20-39. In all welfare regimes except social democratic and conservative, happiness declines monotonically with number of children so that childless people are happiest and those with four or more children are the least happy. In the social democratic welfare regime, happiness declines until parity two, but then starts to rise, and is the same for those with four or more children as it is for childless people. In the continental European countries with conservative welfare regimes, happiness is relatively flat by parity. This partially supports our hypothesis that the relationship between happiness and childbearing would be the least negative in countries with strong welfare states, however for social democratic countries only above parity three. Moreover, at parity three and above, happiness is lowest for those in former socialist, southern European, and developing countries, groups of countries with lower state support for families with small children.

\section{FIGURES 7A AND 7B ABOUT HERE}

Figure $7 \mathrm{~b}$ shows the happiness-fertility association for the age group 40 and above by welfare regime. The association between happiness and fertility is flat for social democratic, conservative, and developing countries' welfare regimes. For the liberal regime, there is weak indication that first children may be associated with decreased happiness. For former socialist countries there is a strong positive association between fertility and happiness so that those with three children are happiest. The negative association between fertility and happiness in the age group 20-39 was strongest for the former socialist countries demonstrating the importance of the life cycle stage in the happiness-fertility relationship. Happiness was also significantly higher 
among those with one child in southern European countries, underlining the value of familial support in this region. Our hypothesis about the importance of children at older ages in states with weak welfare states partially held up. Older respondents in both former socialist states and in southern European states were significantly happier with children than those without. These countries have much weaker welfare states than continental or Nordic countries and rely much more on familial support. We did not however, find a significantly positive relationship for developing countries which also have lower state support than social democratic or conservative countries. However, the unrepresentative nature of the samples in developing countries might oversample wealthy and urban respondents and therefore underestimate the degree to which parents need to rely on children for old age support.

Taken together, the results by welfare regime suggest that the negative association between fertility and happiness in young adult ages is weakest in social democratic and conservative welfare regimes, and the positive association between fertility and happiness in mid- to old ages is strongest in former socialist countries. These country groups include states with mostly low or very low fertility rates (for example, Sweden year 2005 TFR $=1.77$, Bulgaria year $2005 \mathrm{TFR}=1.31$, Czech Republic year $1999 \mathrm{TFR}=1.13$ ). In the social democratic and conservative states, comparatively high happiness levels for those with children may be related to the policies aimed at collectively alleviating the burden an individual faces in childrearing. In the former socialist states, the positive association between happiness and fertility at mid- to older ages may be related to the long-standing tradition of governments to promote pronatalist ideas and policies, both before and after the collapse of the Soviet Union (Zhurzhenko 2001; Yelizarov 2008) and to the increasingly important role of adult children in providing care for their elderly parents in the post-Soviet era (Iecovich et al. 2004). 
Analyses by Stage of Fertility Decline

We next analyze how the happiness-fertility link depends on the stage of the fertility decline. Figure 8a shows the association between fertility and happiness by overall fertility level for the age group 20-39. The figure indicates that in all fertility regimes, with the exception of lowest-low fertility $(\mathrm{TFR}<1.3)$, happiness declines with the number of children so that those with none or only one child are happiest, and those with three or more children are least happy. In lowest-low fertility regimes, the decline in happiness by parity stops at parity three, and those with four or more children are happier than those with only one child but not quite as happy as childless people.

\section{FIGURES 8A AND 8B ABOUT HERE}

Figure $8 \mathrm{~b}$ presents similar results for the age group 40 and above. The figure indicates a gradient in the happiness-fertility relationship, similar to what was observed for age. In high fertility regimes, the happiness-fertility relationship is flat, but the lower the overall fertility level, the more positive the happiness-fertility relationship becomes, strongest in the lowest-low fertility countries. The results by stage of fertility decline suggest that the demographic transition modifies the fertility-happiness relationship in a straightforward, yet unexpected way. The lower the overall fertility of the society, the happier those are who have children compared to those without. This may be because of selection of those who value children the most into childbearing. 


\section{Discussion}

This paper examined the relationship between fertility and well-being globally, considering both individual and contextual level factors. We find that globally, happiness decreases with the number of children. This association, however, is strongly modified by individual and contextual factors. Most importantly, we find that the association between happiness and fertility evolves from negative to neutral to positive above age 40 , and is strongest among those who are likely to benefit most from upward intergenerational transfers. This age gradient is present for both sexes, at all income levels, for those in good and bad health, for those who are partnered and who are not, for all welfare regimes, at all stages of fertility decline, and for our period of study from 1981 to 2005 . In addition, analyses by welfare regime show that the negative fertility-happiness link at young adult ages is weakest in countries with high public support for families, and that the positive association at ages above 40 is strongest in countries where old-age support depends mostly on the family.Overall, these results suggest that children are a long-term investment in well-being, and highlight the importance of both the life-cycle stage and macro contexts the happiness-fertility association.

Prior research has found differences in the relationship between fertility and happiness among the elderly versus non-elderly. Among the non-elderly in the U.S., those with children have similar or higher levels of distress than those without children (Cleary and Mechanic 1983; Gore and Mangione 1983; Lovell-Troy 1983; McLanahan and Adams 1987). However, prior research focusing on the U.S. has not found significant differences in life satisfaction between elderly parents and elderly childless people (Connidis and McMullin 1993; Koropeckyj-Cox et al. 2007; Rempel 1985). We document more subtle age differences in the relationship between happiness and fertility throughout the life course. We find that in the youngest age groups, 
happiness decreases approximately monotonically with the number of children. However, at ages 30-39, the negative association disappears and at older ages the association between the number of children and happiness changes to positive.

There are several possible mechanisms that could cause the observed age gradient in the happiness-fertility association. For example, the age gradient could indicate period or cohort differences in the happiness-fertility link. Our analysis, however, showed that the gradient exists independently of survey period. In addition, the age gradient exists independently of sex, income, partnership status, health status, welfare regime, and stage of demographic transition. Thus the age gradient may be better explained by the life cycle. When parents and children get older, children usually leave the parental home which may decrease the negative effect the children have on the quality of spousal relationships and on the amount of support provided for partners (Pleck 1983). In addition, and potentially more importantly, at younger ages the time and monetary costs of raising children are generally higher than they are at older ages. ${ }^{6}$ As children get older, they become more independent and require less care and fewer resources. As children reach adulthood, when parents are approximately 40-60 years old, the children may become a resource themselves, providing financial and emotional support and care for aging parents. This explanation for the age gradient in the association between happiness and fertility would imply that older people who are more in need of kin support gain more from having children than those who are more independent. Our findings that the positive fertility-happiness association is stronger for those in poor health than those in good health, and for the Former Socialist States than for other welfare regimes are consistent with this explanation.

A theme in the literature is that women and men experience the transition to parenthood in different ways (Cowan et al. 1985; LaRossa and LaRossa 1981; Umberson and Williams 
1999). Women may experience more costs to having children than men, especially in stress and mental well-being (Scott and Alwin 1989; Simon 1992). Some have argued that this is because women are more often the primary caregiver (Ross and Van Willigen 1996). However, it is unclear whether parenthood is differentially related to mental health for women and men (Nomaguchi and Milkie 2003). Unlike prior literature we find that the negative association between happiness and children during prime childbearing years does not differ by sex. The sex difference in the happiness-fertility association, however, may vary by context and should be explored in future work.

The degree to which parenting might affect well-being may depend on marital status and socioeconomic position (Ross and Huber 1985; Umberson and Williams 1999). In the U.S., single mothers are more likely to report higher levels of stress than married mothers (Avison 1995), but this may be confounded by differences in socioeconomic position by marital status. Therefore in investigating childrearing and happiness, it is important to take socioeconomic position into account. In our analyses we control for socioeconomic position and find little difference in the relationship between fertility and happiness between the partnered and unpartnered. We also tested for differences by socioeconomic position in the relationship between fertility and happiness. We find that while differences by income groups are small in magnitude, the negative effects of children on happiness below age 40 are strongest among those with lowest incomes and weakest among those with highest incomes. As shown by Ross and Huber (1985), children increase economic hardship. A high income may help alleviate the burden of raising kids, for example through childcare. A high income may also be a proxy for postponement, so that the high income group may include more people who in their 30s who are 
voluntarily childless or have only one child, whereas the low income group may include more involuntary low fertility.

Our analysis of the fertility-happiness link by health status did not reveal qualitative, but did reveal small quantitative differences. For those in good and poor health, the association of fertility with happiness changes from negative to positive as age increases. However, the negative association at young adult ages is weaker for those in poor health than for those in good health, and the positive association at mid- to old ages is stronger for those in poor health than for those in good health. This may be related to the care and support adult children provide to their parents. Among the healthy, the demand for such care is lower, potentially explaining why the positive association of children and happiness is weaker than it is for less healthy parents.

In contrast to research conducted in the U.S. where parents report similar to slightly higher distress than non-parents, research in Europe has found either insignificant or slightly positive associations between children and life satisfaction (Bergman and Daukantaite 2006; Daukantaite and Zukauskiene 2006; Dykstra and Wagner 2007; Hansen et al.2009; Kohler et al. 2005; Savolainen et al. 2001). This may be because the family-friendly policies in strong European welfare states help new parents cope with the stress of combining work and family and alleviate the financial burdens on parents. We found that the negative association between fertility and happiness at young ages is weakest in social democratic and conservative welfare regimes, where the public support for parenthood is strongest. However, we also find that the positive association between fertility and happiness above age 40 is strongest in former socialist and southern European countries. This may be related to the strong pronatalist policies promoted by some of the former socialist states, which may influence attitudes towards parenthood, and 
also to the important role of adult children in providing care for their elderly parents in these states.

We also examine how the relationship between happiness and fertility varies by the fertility of the society. We find that countries at different stages in the demographic transition have different relationships between fertility and happiness. The lower the overall fertility, the stronger the positive relationship between having children and happiness at older ages. This may be because of two related factors. The first is selection. In low fertility societies, those who value children the most decide to have children, and childlessness may be voluntary. In higher fertility contexts, social pressure may force a less select group of people to have children. Therefore the association may reflect compositional differences rather than causal effects. Second, norms about childbearing differ in places with different fertility levels. The stigma associated with being childless may be lower in countries with low levels of fertility, whereas it may be higher in places where fertility is high and childlessness less common. These differences may be reflected in the happiness level of our reference group, the childless. However, such force should cause the happiness difference between those who have children and those who are childless to be small in low fertility countries where childlessness is (by the argument) voluntary, and large in high fertility countries where childlessness is outside the norm and rare. We observe the opposite. Further, when we compare those with two children to those with only one child, we find that the happiness difference favoring those with two children is largest in countries with the lowest overall fertility. These results suggest that the social norms and potential stigma related to childbearing and childlessness are not the forces driving our results.

Our analysis sheds light on the puzzling discrepancy between the widespread belief that children bring happiness and the fact that most research finds either a negative or insignificant 
relationship between parenthood and well-being. In the early stages of parenting, the positive aspects of having children are difficult to detect in surveys because they may be sporadic and be dominated by the negative aspects such as lack of sleep, concerns about the safety and development of the child, and financial strains, especially when answering questions about global happiness. Powdthavee (2009) calls this phenomenon where parents' responses reflect more of the negative aspects of parenting than the positive, a focusing illusion. However, our finding that parents above age 40 are happier than those without children suggests that at a later life stage the positive aspects of parenting, and potentially also grandparenting, might dominate and be easier to detect. Moreover, our results mirror the life-cycle net production pattern of humans: at young ages, consumption dominates production, but at ages close to 20 (when parents are approximately 40-60 years) productions starts to dominate consumption (Lee 1994). These ages correspond to the ages at which we observe childless people to be less happy than those with children.

There are four major limitations to this analysis. Choice of the reference group, childless people, may be criticized in two ways. First, as childlessness is rare in most societies, this group of people is probably different from those who have one or more children on many unobserved dimensions, including health, social skills, and career perceptions. However, implicit in our regression analyses, and explicit in our discussions, is the comparison of those with two or more children to those with only one child; those with three or more children to those with one or two children, and so on. In fact, the effect of having one additional child (compared to those with one fewer child) can easily be seen from the slopes of the results in Figures 1 to 8. A potentially more important criticism is that the childless group may be compositionally different in different contexts. For example, those who intrinsically strongly desire to have children are likely to have 
them both in high and low fertility societies, whereas those who would rather not have children may forego having them more often in low fertility societies, but may have children due to social pressures in higher fertility societies. Thus the proportions of childless people and the degree of selection may differ by context. However as discussed above, our results also show comparisons of those with different numbers of children. Therefore the potential specificity of the childless group does not prevent a meaningful interpretation of our results.

Second, having children is a decision, which exposes our regression results to endogeneity bias. More specifically, although we control for a large array of observed characteristics, we do not control for unobservable differences in people's preferences for children. An example of a study on the happiness-fertility link in which unobserved characteristics are partially controlled for is that of Kohler and colleagues (2005), which uses twin data to control for unobserved social and genetic differences. However, the results by Kohler and colleagues (2005) indicate that the sign and magnitude for the coefficient for the number of children in a regression on happiness is in most cases the same in standard ordinary least squares regressions and in twin-differences models. This suggests that the unobserved heterogeneity bias in our ordinary least squares regression results may not be large.

Third, the design of our study assumes that life events such as having children matter for happiness. This is in contrast with the setpoint theory of happiness, which asserts that a large fraction of variation in well-being is due to social or biological endowments, and while life events may temporarily change experienced well-being level, this change is transitory (Kahneman 1999). However, several recent studies have demonstrated that important life events do change happiness and not just temporarily (Kohler et al. 2005; Zimmerman and Easterlin 2006). Our results, which suggest that significant life events such as having a child have long- 
lasting but potentially time-varying effects on happiness, are consistent with these findings which suggest that happiness is not set to a point.

Lastly, we use a synthetic cohort constructed from cross-sectional data to examine the association between fertility and happiness throughout the life cycle. This approach is widely used because of the ease at which comparisons can be made across age groups. However, it makes it difficult to generalize about the life course experience, as it uses many cohorts which experienced different life course trajectories. To make sure our results are not driven by cohort differences, we conducted the analyses separately for two time periods (1981-1996 and 19972007) and found that our key results on the age-gradient in the happiness-fertility association was present in both periods. These results add to the evidence suggesting that the association is age, not period or cohort related. Still, future research would benefit from longitudinal data in examining actual life cycle experiences and to compare the associations between fertility and happiness across parities, periods, and cohorts. Clark et al. (2008) make an important step towards this end in comparing life satisfaction before and after important life events, including the birth of a child.

In discussing the associations between fertility and happiness, we have focused on explanations from which the direction of influence goes from fertility to happiness. The effect of happiness on demographic behavior has been much less studied but is an area for upcoming research (Diener et al. 1999). Although we do not know if happier people have more children than less happy people, having children may be a strategy to improve happiness, for example by increasing the level of certainty in life (Friedman, Hechter, and Kanazawa 1994). There is also some recent evidence that people who have higher expected happiness from having a child are more likely to have one in the short to medium term (Billari and Kohler 2009). However, our 
results show that people in their twenties and thirties with children are less happy than those without. We can reconcile this in two ways. First, people seem to poorly predict how children affect their lifestyles and underestimate the costs (Belsky, Ward, and Rovine 1986). Second, people may place a high value on the gains in happiness in older ages from having children more than the short term costs. Further research is needed to compare these and other mechanisms which may explain why people still have children, even though the immediate effects on subjective well-being seem to be negative.

Our analysis contributes to the literature on well-being and fertility in several ways. To the authors' knowledge, this is the first analysis that takes a global, cross-cultural look at the relationship between fertility and happiness. We find both similarities and differences in the happiness-fertility relationship across contexts. Our strongest finding, which has not been well established before, is that the link between happiness and fertility evolves from negative to neutral to positive over age. The fact that the happiness-fertility association depends so strongly on age might explain some of the discrepancies in earlier literature. This age gradient is present for both sexes, at all income levels, for those in good and bad health, for those who are partnered and who are not, for all welfare regimes, at all stages of fertility decline, and for at least the period from 1981 to 2005 . We find that those who are likely to have a higher demand for care from kin at mid- to older ages are more likely to gain in terms of happiness from having children. This point is illustrated by the findings that the positive happiness-fertility association at ages above 40 is stronger for those in poor health than for those in good health, and in the former socialist countries where old-age support is largely based on family ties than in social democratic, conservative or liberal states where much of old-age support comes from the state or from own savings. Taken together, these findings indicate that the relationship between the 
number of children and well-being is sensitive to context, and highlight the importance of the broader context such as the country's stage in the fertility transition, as well as individual level factors such as the stage in the life-cycle and financial resources. 


\section{Notes}

The authors gratefully acknowledge support from grants from the US National Institute on Aging (T32 AG 000177) and National Institute of Child Health and Human Development (T32 HD 007242) awarded to the University of Pennsylvania. The authors are also grateful to Francesco Billari, Andy Fenelon, Richard Easterlin, Wendy Sigle-Rushton and two anonymous reviewers for advice on this analysis. Participants at the 2010 Annual Meeting of the Population Association of America in Dallas also provided helpful comments.

${ }^{1}$ We include the $7^{\text {th }}$ decile of self-reported income in the high income category. Otherwise the high income group would have been small, comprising only 14 percent of the sample. With the current classification of income groups, $36.5 \%$ of respondents are in the low income group, $41.1 \%$ in the middle income group, and $22.4 \%$ in the high income group.

${ }^{2}$ The results shown in the paper are estimated using OLS regression and thus assume the cardinality of happiness. However, similar to the finding of Ferrer-i-Carbonell and Frijters (2004) that assuming the ordinality or cardinality of happiness scores makes little difference, our results are robust to estimation using ordered logit regressions.

${ }^{3}$ The Ethiopian and Dominican samples are considerably younger than the overall sample. The mean age of the sample is 29.9 for Ethiopia, 28.8 for the Dominican Republic, and 41.5 for the whole sample. Moreover, as mentioned above, the sampling for the World Values Surveys is not random, especially in developing countries.

${ }^{4}$ The childless are an important reference group in examining the relationship between parenthood and well-being. Thus, we graph regression results in reference to parity 0 . However, comparisons of happiness at various fertility levels (i.e. the effect of having one additional child) is possible by examining the slopes of results in Figures 1-8. These comparisons are implicitly in our regression analyses and explicitly in our discussion.

${ }^{5}$ There are no statistically significant differences between the partnered and unpartnered in either age group 20-39 or 40+.

${ }^{6}$ Our data did not have information on the ages of children or whether the children are present in the household. Therefore we have to use parent's age as a proxy for the family life cycle. 


\section{REFERENCES}

Aassve, A., Goisis, A., Ruggeri, G., and Sironi, M. 2008. "Childbearing and Happiness Across Europe." Carlo F. Dondena Cneter for Research on Social Dynamics, Bocconi University, Milan. Working Paper.

Avison, W. 1995. "Roles and resources: The effects of work and family context on women's psychosocial resources and psychological distress." Research in community and mental health 8:233-256.

Baumeister, R.F. 1991. Meanings of life. New York: Guilford Press.

Belsky, J., Ward, M. J., and Rovine, M. 1986. Prenatal expectations, postnatal experiences and the transition to parenthood. Pp.119-145 In Ashmore, R.D. \& Brodinsky, D.M. (eds.), Thinking about the family: Views of parents and children. Hillsdale, NJ: Erlbaum.

Bergman, L.and D. Daukantaite. 2006. "The importance of social circumstances for Swedish women's subjective wellbeing." International Journal of Social Welfare 15(1):27-36.

Billari, F.C. 2008. "The Happiness Commonality: Fertility Decisions in Low-Fertility Settings" Keynote address to panel on "Very low fertility" Conference on How Generations and Gender Shape Demographic Change: Toward policies based on better knowledge, UNECE. Geneva. 14-16 May 2008. http://www.unece.org/pau/_docs/ggp/2008/GGP_2008_GGConf_Publ_1_Chapter-1.pdf

Billari, F.C. and Kohler, H.P. 2009. "Fertility and Happiness in the XXI Century: Institutions, Preferences, and their Interactions". 2009 Annual Meeting of the Population Association of America Conference Proceedings. April, 2009. Detroit, MI.

Blake, J. 1979. "Is zero preferred? American attitudes toward childlessness in the 1970s." Journal of Marriage and the Family 41(2):245-257.

Borooah, V.K. 2006. "How much happiness is there in the world? A cross-country study." Applied Economics Letters 13(8):483-488.

Caldwell, J.C. 1978. "Theory of Fertility: From High Plateau to Destabilization." Population and Development Review 4(4):553-577.

Cantril, H. 1965. The pattern of human concerns. New Brunswick, N.J.,: Rutgers University Press.

Central Intelligence Agency of the U.S. (2010) CIA World Factbook. Data downloaded from https:/www.cia.gov/library/publications/the-world-factbook/

Clark, A.E., E. Diener, Y. Georgellis, and R. E. Lucas. 2008. "Lags and Leads in Life Satisfaction: A Test of the Baseline Hypothesis. The Economic Journal 118:F222-F243.

Cleary, P.D.and D. Mechanic. 1983. "Sex Differences in Psychological Distress among Married People." Journal of Health and Social Behavior 24(2):111-121.

Connidis, I.A. 2001. Family ties \& aging. Thousand Oaks, Calif.: Sage Publications.

Connidis, I.A.and J.A. McMullin. 1993. "To Have or Have Not - Parent Status and the Subjective Well-Being of Older Men and Women." Gerontologist 33(5):630-636.

Cowan, C.P., P.A. Cowan, G. Heming, E. Garrett, W.S. Coysh, H. Curtisboles, and A.J. Boles. 1985. "Transitions to Parenthood - His, Hers, and Theirs." Journal of Family Issues 6(4):451-481.

Crohan, S.E. 1996. "Marital quality and conflict across the transition to parenthood in African American and white couples." Journal of Marriage and the Family 58(4):933-944.

Daukantaite, D.and R. Zukauskiene. 2006. "Swedish and Lithuanian employed women's subjective well-being." International Journal of Social Welfare 15:S23-S30. 
Deaton, A. 2008. "Income, health, and well-being around the world: Evidence from the Gallup World Poll." Journal of Economic Perspectives 22(2):53-72.

Diener, E., J.F. Helliwell, and D. Kahneman. 2010. International differences in well-being. Oxford ; New York: Oxford University Press.

Diener, E., E.M. Suh, R.E. Lucas, and H.L. Smith. 1999. "Subjective well-being: Three decades of progress." Psychological Bulletin 125(2):276-302.

Dykstra, P.A.and M. Wagner. 2007. "Pathways to childlessness and late-life outcomes." Journal of Family Issues 28(11):1487-1517.

Easterlin, R.A. 1995. "Will Raising the Incomes of All Increase the Happiness of All." Journal of Economic Behavior \& Organization 27(1):35-47.

Esping-Andersen, G. 1990. The three worlds of welfare capitalism. Cambridge, UK: Polity Press.

Ferrer-i-Carbonell, A. and P. Frijters. 2004. "How Important is Methodological for the Estimates of the Determinants of Happiness? The Economic Journal 114:641-659.

Friedman, D., M. Hechter, and S. Kanazawa. 1994. "A Theory of the Value of Children." Demography 31(3):375-401.

Gallagher, S.K.and N. Gerstel. 2001. "Connections and constraints: The effects of children on caregiving." Journal of Marriage and the Family 63(1):265-275.

Goldsteen, K.and C.E. Ross. 1989. "The Perceived Burden of Children." Journal of Family Issues 10(4):504-526.

Gore, S.and T.W. Mangione. 1983. "Social Roles, Sex Roles and Psychological Distress Additive and Interactive Models of Sex-Differences." Journal of Health and Social Behavior 24(4):300-312.

Hakim, C. 2000. Work-lifestyle choices in the 21st Century : preference theory. New York: Oxford University Press.

Hansen, T., B. Slagsvold, and T. Moum. 2009. "Childlessness and Psychological Well-Being in Midlife and Old Age: An Examination of Parental Status Effects Across a Range of Outcomes." Social Indicators Research 94(2):343-362.

Hobcraft, J. 2006. "The ABC of demographic behaviour: How the interplays of alleles, brains, and contexts over the life course should shape research aimed at understanding population processes." Population Studies-a Journal of Demography 60(2):153-187.

Hoffman, L.and J. Manis. 1979. "The value of children in the United States: A new approach to the study of fertility." Journal of Marriage and the Family 41(3):583-596.

Hoffman, L.W., A. Thornton, and J.D. Manis. 1978. "Value of Children to Parents in UnitedStates." Journal of Population 1(2):91-131.

Iecovich, E., M. Barasch, J. Mirsky, R. Kaufman, A. Avgar, and A. Kol-Fogelson. 2004. "Social support networks and loneliness among elderly Jews in Russia and Ukraine." Journal of Marriage and the Family 66(2):306-317.

Inglehart, R., C. Aguir, A. Ahmad, A. Aliev, R. Alishauskiene, and V. Andreyenkov. 2000. "World Values Surveys and European Values Surveys, 1981-84, 1990-93, and 1995-97 [Computer file]. ICPSR version." Ann Arbor, MI: Institute for Social Research.

Jones, R.K.and A. Brayfield. 1997. "Life's greatest joy?: European attitudes toward the centrality of children." Social Forces 75(4):1239-1269.

Kahneman, D. 1999. Objective Well-Being. Pp. 3-25 In Kahneman, D., Diener E., and Schwarz, N.(eds.), Well-Being: The Foundations of Hedonic Psychology. New York: Russell Sage Foundation. 
Kohler, H.P., J.R. Behrman, and A. Skytthe. 2005. "Partner plus children = happiness? The effects of partnerships and fertility on well-being." Population and Development Review 31(3):407-445.

Kohler, H.P., F.C. Billari, and J.A. Ortega. 2002. "The emergence of lowest-low fertility in Europe during the 1990s." Population and Development Review 28(4):641-680.

Koropeckyj-Cox, T., A.M. Pienta, and T.H. Brown. 2007. "Women of the 1950s and the "normative" life course: The implications of childlessness, fertility timing, and marital status for psychological well-being in late midlife." International Journal of Aging \& Human Development 64(4):299-330.

LaRossa, R.and M.M. LaRossa. 1981. Transition to parenthood : how infants change families. Beverly Hills: Sage Publications.

Lavee, Y., S. Sharlin, and R. Katz. 1996. "The effect of parenting stress on marital quality: An integrated mother-father model." Journal of Family Issues 17(1):114-135.

Lechner, M. 2001. "The empirical analysis of East German fertility after unification: An update." European Journal of Population-Revue Europeenne De Demographie 17(1):61-74.

Lee, M. 2009. "Transition to Below Replacement Fertility and Policy Response in Taiwan." The Japanese Journal of Population 7(1):71-86.

Lee, R. 1994. The Formal Demography of Population Aging, Transfers, and the Economic Life Cycle. Pp.8-40 In Martin, LG \& Preston, S.H. (eds.), The Demography of Aging, Washington DC: National Academy Press.

Lovell-Troy, L. 1983. "Anomia among employed wives and housewives: An exploratory analysis." Journal of Marriage and the Family 45(2):301-310.

McLanahan, S.and J. Adams. 1987. "Parenthood and Psychological Well-Being." Annual Review of Sociology 13:237-257.

McQuillan, J., R.A.T. Stone, and A.L. Greil. 2007. "Infertility and life satisfaction among women." Journal of Family Issues 28(7):955-981.

Mirowsky, J.and C.E. Ross. 2003. Social causes of psychological distress. New York: Aldine de Gruyter.

Nomaguchi, K.M.and M.A. Milkie. 2003. "Costs and rewards of children: The effects of becoming a parent on adults' lives." Journal of Marriage and the Family 65(2):356-374.

Park, K. 2002. "Stigma management among the voluntarily childless." Sociological Perspectives 45(1):21-45.

Pleck, J. 1983. Husbands' Paid Work and Family Roles: Current Research Issues. Pp.251-333 In Lopata, H. \& Pleck, J. (eds.), Research in the Interweave of Social Roles Vol. 3. Families and Jobs. Greenwich, CT: JAI.

Powdthavee, N. 2009. "Think having children will make you happy?" The Psychologist 22(4): 308-310.

Rempel, J. 1985. "Childless Elderly: What Are They Missing?" Journal of Marriage and the Family 47(2):343-348.

Ross, C.E.and J. Huber. 1985. "Hardship and Depression." Journal of Health and Social Behavior 26(4):312-327.

Ross, C.E., J. Mirowsky, and K. Goldsteen. 1990. "The Impact of the Family on Health: the Decade in Review." Journal of Marriage and the Family 52(4):1059-1078.

Ross, C.E.and M. VanWilligen. 1996. "Gender, parenthood, and anger." Journal of Marriage and the Family 58(3):572-584.

Sanchez, L.and E. Thomson. 1997. "Becoming mothers and fathers: Parenthood, gender, and the 
division of labor." Gender \& Society 11(6):747-772.

Savolainen, J., E. Lahelma, K. Silventionen, and A.H. Gauthier. 2001. "Parenthood and psychological well-being in Finland: Does public policy make a difference?" Journal of Comparative Family Studies 32(1):61-75.

Scott, J.and D.F. Alwin. 1989. "Gender Differences in Parental Strain: Parental Role or Gender Role." Journal of Family Issues 10(4):482-503.

Sieber, S.D. 1974. "Toward a Theory of Role Accumulation." American Sociological Review 39(4):567-578.

Simon, R.W. 1992. "Parental Role Strains, Salience of Parental Identity and Gender Differences in Psychological Distress." Journal of Health and Social Behavior 33(1):25-35.

Thornton, A.and L. Young-DeMarco. 2001. "Four decades of trends in attitudes toward family issues in the United States: The 1960s through the 1990s." Journal of Marriage and the Family 63(4):1009-1037.

Umberson, D.and W.R. Gove. 1989. "Parenthood and Psychological Well-Being: Theory, Measurement, and Stage in the Family Life Course." Journal of Family Issues 10(4):440462.

Umberson, D. and Williams K. 1999. Family Status and Mental Health. Pp.225-253 In Handbook of the Sociology of Mental Health. (ed.) Aneshensel, C.S. \& Phelan, J.C. New York: Kluwer Academic/Plenu.

World Bank 2010. World Development Indicators Online Database (The World Bank Group, Washington, D.C., 2008). [Online] Available at http://www.worldbank.org. Accessed on May 242010.

Yelizarov, V. 2008. "Demographic Policy in Russia: from reflection to action." United Nations Moscow.

Zhurzhenko, T. 2001. Women and Reproduction in Post-Soviet Ukraine: Nationalism, Statebuilding and Family Politics. In Kennan Institute Workshop on the Role of Women in Post-Communist Transitions Conference Proceedings. Washington, D.C.

Zimmermann, A.C. and R.A. Easterlin. 2006. "Happily Ever after? Cohabitation, Marriage, Divorce, and Happiness in Germany." Population and Development Review 32(3):511528. 
TABLES

TABLE 1 Unweighted Sample Characteristics by Country, $(\mathrm{N}=\mathbf{2 0 1 , 9 8 8 )}$

\begin{tabular}{|c|c|c|c|c|c|}
\hline Country & $\#$ & $\begin{array}{l}\text { Mean } \\
\text { Happiness }\end{array}$ & $\begin{array}{l}\text { Mean \# } \\
\text { Children }\end{array}$ & $\begin{array}{l}\text { Mean } \\
\text { Age }\end{array}$ & $\begin{array}{l}\text { Percent } \\
\text { Married }\end{array}$ \\
\hline All Countries & 201988 & 3.03 & 1.97 & 41.50 & 61.90 \\
\hline Tanzania & 1001 & 3.49 & 2.81 & 38.30 & 52.90 \\
\hline El Salvador & 977 & 3.47 & 2.39 & 37.70 & 39.40 \\
\hline Venezuela & 2104 & 3.46 & 2.27 & 36.40 & 41.60 \\
\hline Nigeria & 3872 & 3.39 & 2.23 & 32.50 & 56.90 \\
\hline Netherlands & 1313 & 3.38 & 2.02 & 43.90 & 70.40 \\
\hline Ireland & 1147 & 3.37 & 2.65 & 45.70 & 67.80 \\
\hline Saudi Arabia & 1303 & 3.34 & 2.19 & 32.20 & 59.60 \\
\hline Switzerland & 1976 & 3.34 & 1.59 & 49.20 & 56.30 \\
\hline Trinidad and Tobago & 973 & 3.34 & 2.09 & 42.40 & 38.80 \\
\hline USA & 3962 & 3.34 & 2.02 & 45.90 & 59.20 \\
\hline Sweden & 2466 & 3.33 & 1.55 & 45.80 & 49.80 \\
\hline Australia & 2998 & 3.32 & 1.82 & 45.80 & 56.30 \\
\hline Thailand & 1477 & 3.32 & 2.16 & 45.60 & 69.70 \\
\hline Belgium & 3516 & 3.31 & 1.81 & 46.40 & 64.80 \\
\hline Malaysia & 1195 & 3.31 & 1.64 & 31.80 & 50.00 \\
\hline Colombia & 2962 & 3.30 & 1.99 & 36.60 & 42.00 \\
\hline Luxembourg & 589 & 3.30 & 1.41 & 42.50 & 61.50 \\
\hline Denmark & 674 & 3.27 & 2.29 & 47.20 & 75.50 \\
\hline New Zealand & 930 & 3.27 & 2.13 & 46.20 & 60.70 \\
\hline Philippines & 1181 & 3.27 & 2.74 & 38.80 & 72.60 \\
\hline Britain & 2412 & 3.26 & 1.53 & 46.30 & 65.80 \\
\hline Cyprus & 1031 & 3.26 & 1.71 & 41.60 & 64.80 \\
\hline Norway & 952 & 3.25 & 1.69 & 43.40 & 55.20 \\
\hline Vietnam & 2412 & 3.25 & 2.37 & 41.50 & 74.30 \\
\hline Canada & 3026 & 3.24 & 1.89 & 44.30 & 55.20 \\
\hline Ghana & 1421 & 3.24 & 1.99 & 33.90 & 46.20 \\
\hline Austria & 2549 & 3.23 & 1.76 & 46.80 & 65.90 \\
\hline Andorra & 936 & 3.21 & 1.05 & 40.40 & 40.00 \\
\hline Mali & 981 & 3.21 & 2.87 & 36.70 & 69.50 \\
\hline Mexico & 5154 & 3.20 & 2.48 & 37.20 & 56.50 \\
\hline South Africa & 7461 & 3.20 & 1.98 & 38.50 & 45.90 \\
\hline France & 2683 & 3.19 & 1.97 & 44.80 & 62.40 \\
\hline Malta & 931 & 3.19 & 1.95 & 45.60 & 70.10 \\
\hline Finland & 1696 & 3.17 & 1.60 & 44.90 & 43.90 \\
\hline Indonesia & 2515 & 3.17 & 2.16 & 39.20 & 17.70 \\
\hline Japan & 3487 & 3.16 & 1.80 & 47.40 & 80.20 \\
\hline Uganda & 526 & 3.12 & 2.21 & 31.40 & 43.70 \\
\hline Taiwan & 1875 & 3.11 & 2.01 & 42.80 & 68.80 \\
\hline Argentina & 2590 & 3.10 & 2.11 & 43.60 & 55.40 \\
\hline Chile & 4040 & 3.10 & 2.26 & 41.80 & 58.20 \\
\hline Brazil & 3703 & 3.09 & 2.24 & 39.20 & 52.10 \\
\hline Turkey & 7545 & 3.07 & 2.20 & 36.90 & 72.50 \\
\hline
\end{tabular}

NOTE: Happiness is measured on a linear scale from 1 (not at all happy) to 4 (very happy).

SOURCE: World Values Surveys 1981-2005 
TABLE 1 Continued.

\begin{tabular}{|c|c|c|c|c|c|}
\hline Country & \# & $\begin{array}{l}\text { Mean } \\
\text { Happiness }\end{array}$ & $\begin{array}{l}\text { Mean \# } \\
\text { Children }\end{array}$ & $\begin{array}{l}\text { Mean } \\
\text { Age }\end{array}$ & $\begin{array}{l}\text { Percent } \\
\text { Married }\end{array}$ \\
\hline Dominican Republic & 325 & 3.06 & 1.19 & 28.80 & 32.60 \\
\hline Spain & 7617 & 3.04 & 1.98 & 46.10 & 67.40 \\
\hline Kyrgyzstan & 982 & 3.03 & 2.05 & 37.30 & 60.20 \\
\hline Morocco & 2318 & 3.03 & 1.79 & 35.60 & 55.60 \\
\hline Uruguay & 909 & 3.01 & 1.98 & 46.50 & 56.20 \\
\hline West Germany & 3981 & 3.01 & 1.53 & 46.10 & 60.10 \\
\hline South Korea & 2388 & 3.00 & 1.65 & 40.00 & 66.60 \\
\hline Burkina Faso & 1170 & 2.99 & 2.52 & 34.30 & 55.20 \\
\hline Egypt & 5636 & 2.99 & 2.68 & 39.80 & 72.70 \\
\hline India & 6556 & 2.99 & 2.67 & 40.20 & 85.70 \\
\hline Algeria & 835 & 2.98 & 2.29 & 37.30 & 52.80 \\
\hline Italy & 3971 & 2.98 & 1.52 & 45.20 & 66.30 \\
\hline Bangladesh & 2833 & 2.96 & 2.33 & 34.60 & 76.70 \\
\hline China & 4541 & 2.96 & 1.88 & 41.90 & 86.10 \\
\hline Pakistan & 2525 & 2.96 & 2.19 & 37.30 & 69.80 \\
\hline Rwanda & 1336 & 2.96 & 2.40 & 34.40 & 52.50 \\
\hline Peru & 3754 & 2.94 & 2.04 & 36.20 & 40.90 \\
\hline East Germany & 2741 & 2.93 & 1.64 & 46.20 & 59.90 \\
\hline Jordan & 1109 & 2.91 & 3.09 & 36.30 & 67.40 \\
\hline Poland & 3657 & 2.91 & 1.94 & 46.30 & 65.80 \\
\hline Czech Republic & 4554 & 2.89 & 1.73 & 46.70 & 66.10 \\
\hline Azerbaijan & 1698 & 2.88 & 1.76 & 36.50 & 63.30 \\
\hline Ethiopia & 1406 & 2.87 & 1.03 & 29.90 & 39.70 \\
\hline Portugal & 1109 & 2.85 & 1.62 & 42.50 & 60.40 \\
\hline Croatia & 1992 & 2.84 & 1.42 & 41.70 & 63.20 \\
\hline Macedonia & 1608 & 2.83 & 1.68 & 42.20 & 73.40 \\
\hline Iran & 1992 & 2.82 & 1.78 & 34.30 & 56.90 \\
\hline Slovenia & 1889 & 2.80 & 1.52 & 44.30 & 60.30 \\
\hline Hungary & 1919 & 2.78 & 1.65 & 47.10 & 65.70 \\
\hline Zambia & 1035 & 2.77 & 1.72 & 29.40 & 31.00 \\
\hline Latvia & 1087 & 2.72 & 1.29 & 42.70 & 52.40 \\
\hline Georgia & 1934 & 2.71 & 1.43 & 40.70 & 60.50 \\
\hline Slovakia & 3116 & 2.70 & 1.88 & 44.30 & 69.40 \\
\hline Estonia & 962 & 2.65 & 1.49 & 43.60 & 57.00 \\
\hline Zimbabwe & 809 & 2.65 & 2.71 & 35.50 & 60.40 \\
\hline Ukraine & 3001 & 2.58 & 1.48 & 45.00 & 67.70 \\
\hline Armenia & 1785 & 2.56 & 1.72 & 38.30 & 59.30 \\
\hline Lithuania & 863 & 2.55 & 1.63 & 44.50 & 66.90 \\
\hline Romania & 2697 & 2.54 & 1.60 & 46.30 & 69.00 \\
\hline Bulgaria & 2490 & 2.50 & 1.55 & 45.90 & 70.30 \\
\hline Russia & 1786 & 2.50 & 1.56 & 46.60 & 62.70 \\
\hline Moldova & 2764 & 2.47 & 1.77 & 42.80 & 67.50 \\
\hline Albania & 1877 & 2.43 & 2.14 & 40.90 & 71.90 \\
\hline Belarus & 1869 & 2.43 & 1.63 & 44.10 & 65.60 \\
\hline
\end{tabular}

NOTE: Happiness is measured on a linear scale from 1 (not at all happy) to 4 (very happy).

SOURCE: World Values Surveys 1981-2005 
TABLE 2 Coefficients from Linear Regression Models Predicting Happiness, Model 1, (N=201,988)

\begin{tabular}{lcccccc}
\hline Variable & Coefficient & SE & t & p value & & 95\% CI \\
\hline Number of Children (None) & & & & & & 0.051 \\
$\quad$ One & 0.041 & 0.005 & 7.95 & 0.000 & 0.031 & 0.072 \\
$\quad$ Two & 0.062 & 0.005 & 13.09 & 0.000 & 0.053 & 0.071 \\
$\quad$ Three & 0.060 & 0.005 & 10.80 & 0.000 & 0.049 & 0.013 \\
$\quad$ Four or more & 0.002 & 0.006 & 0.30 & 0.766 & -0.009 & 0.014 \\
$\quad$ Demographic Variables & & & & & \\
$\quad$ Female & 0.007 & 0.003 & 2.47 & 0.014 & 0.001 & -0.079 \\
$\quad$ Age (15-19) & & & & & -0.175 \\
$\quad$ Ages 20-39 & -0.094 & 0.008 & -11.66 & 0.000 & -0.110 \\
$\quad$ Age 40+ & -0.192 & 0.009 & -22.25 & 0.000 & -0.209 & -0.14 \\
\hline
\end{tabular}

NOTE: Coefficients for country and year dummy variables not shown.

$*$ R squared $=0.12$

*Happiness is measured on a linear scale from 1 (not at all happy) to 4 (very happy)

SOURCE: World Values Surveys 1981-2005 
TABLE 3 Coefficients from Linear Regression Models Predicting Happiness, Model 2, (N=201,988)

\begin{tabular}{|c|c|c|c|c|c|c|}
\hline Variable & Coefficient & SE & $\mathbf{t}$ & p value & \multicolumn{2}{|c|}{$95 \% \mathrm{CI}$} \\
\hline \multicolumn{7}{|c|}{ Number of Children (None) } \\
\hline One & -0.032 & 0.006 & -4.77 & 0.000 & -0.045 & -0.020 \\
\hline Two & -0.034 & 0.006 & -5.40 & 0.000 & -0.046 & -0.022 \\
\hline Three & -0.026 & 0.007 & -3.39 & 0.000 & -0.039 & -0.012 \\
\hline Four or more & -0.055 & 0.007 & -6.64 & 0.000 & -0.069 & -0.041 \\
\hline \multicolumn{7}{|c|}{ Demographic Variables } \\
\hline Female & 0.035 & 0.003 & 11.36 & 0.000 & 0.029 & 0.041 \\
\hline Age (15-19) & & & & & & \\
\hline Ages 20-39 & -0.111 & 0.008 & -13.79 & 0.000 & -0.127 & -0.095 \\
\hline Age $40+$ & -0.181 & 0.009 & -20.88 & 0.000 & -0.198 & -0.164 \\
\hline \multicolumn{7}{|l|}{ Income (High) } \\
\hline Low Income & -0.164 & 0.005 & -34.84 & 0.000 & -0.173 & -0.155 \\
\hline Mid Income & -0.054 & 0.004 & -12.57 & 0.000 & -0.062 & -0.045 \\
\hline \multicolumn{7}{|c|}{ Socioeconomic Status (Low) } \\
\hline Middle & 0.121 & 0.004 & 32.70 & 0.000 & 0.114 & 0.129 \\
\hline High & 0.121 & 0.004 & 42.68 & 0.000 & 0.201 & 0.220 \\
\hline \multicolumn{7}{|c|}{ Marital Status (Married) } \\
\hline Cohabiting & -0.083 & 0.007 & -11.27 & 0.000 & -0.097 & -0.069 \\
\hline Separated/Divorced & -0.277 & 0.007 & -38.12 & 0.000 & -0.291 & -0.263 \\
\hline Widowed & -0.243 & 0.007 & -36.78 & 0.000 & -0.256 & -0.230 \\
\hline Single & -0.157 & 0.006 & -24.95 & 0.000 & -0.169 & -0.144 \\
\hline
\end{tabular}

NOTE: Coefficients for country and year dummy variables not shown.

$*$ R squared $=0.16$

*Happiness is measured on a linear scale from 1 (not at all happy) to 4 (very happy).

SOURCE: World Values Surveys 1981-2005 


\section{FIGURES}

FIGURE 1 Happiness and Number of Children by Age

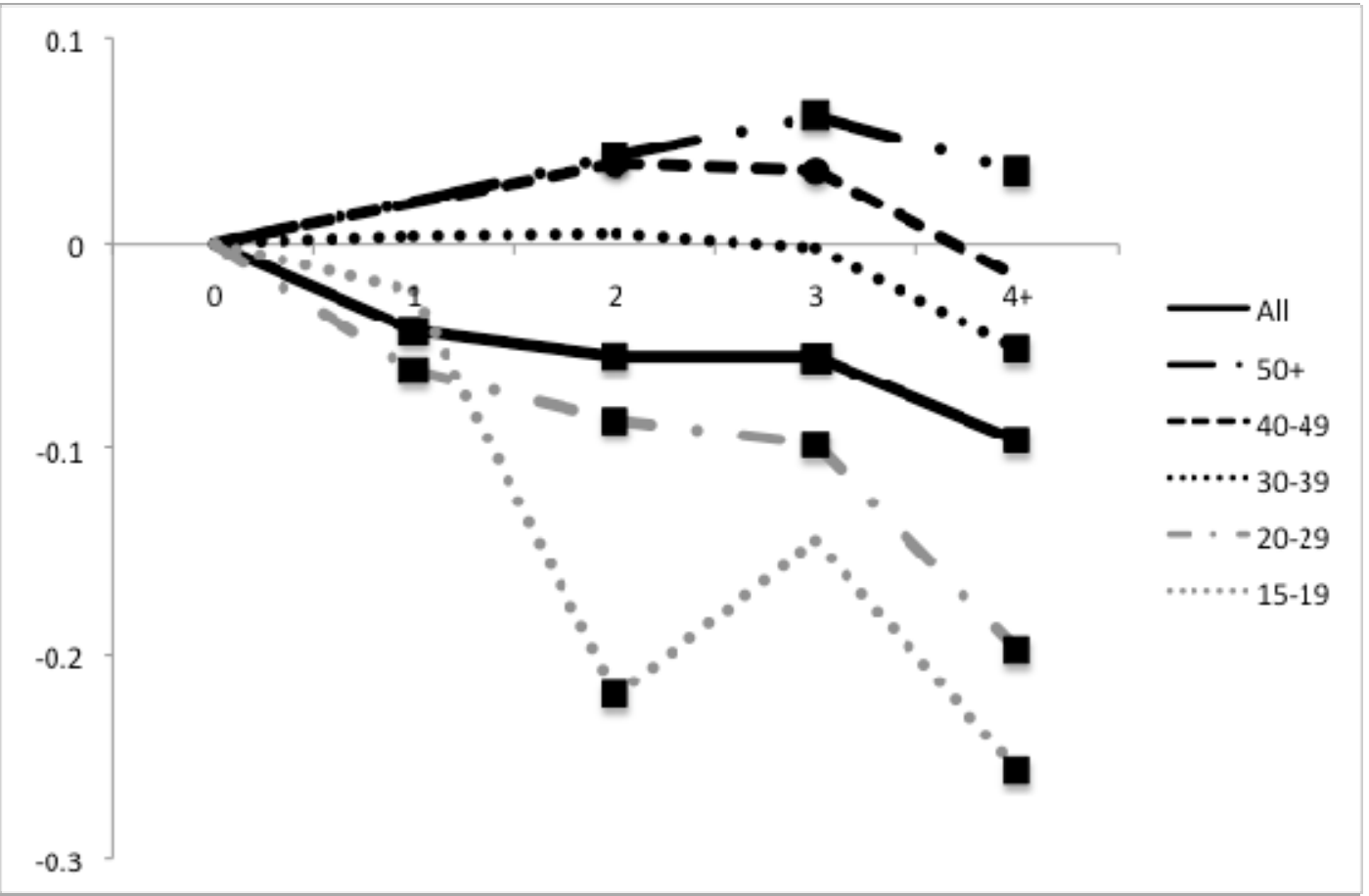

Notes: Lines connect coefficients from regression models predicting happiness (measured on a linear scale from 1 (not at all happy) to 4 (very happy) with number of children $(0,1,2,3,4+)$, controlling for sex, socioeconomic status, income, marital status, country, and year.

च $\mathrm{p}<.05 \bullet \mathrm{p}<.10$

SOURCE: World Values Surveys 1981-2005, N=201,988 
FIGURE 2 Happiness and Number of Children by Age and Survey Period

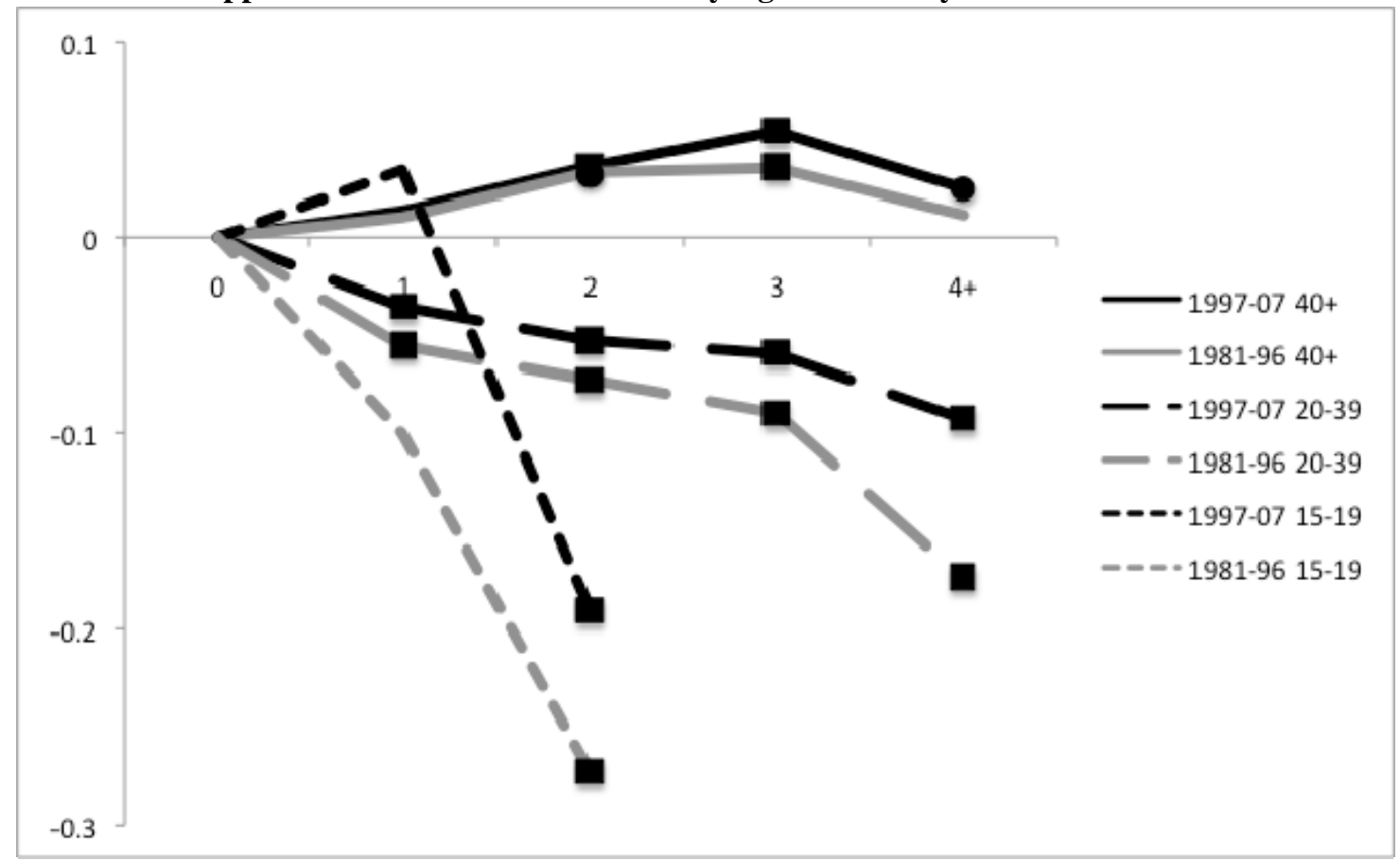

Notes: Lines connect coefficients from regression models predicting happiness (measured on a linear scale from 1 (not at all happy) to 4 (very happy) with number of children $(0,1,2,3,4+)$, controlling for sex, socioeconomic status, income, marital status, country, and year.

- $\mathrm{p}<.05 \bullet \mathrm{p}<.10$

SOURCE: World Values Surveys 1981-2005, N=201,988 
FIGURE 3 Happiness and Number of Children by Age and Sex

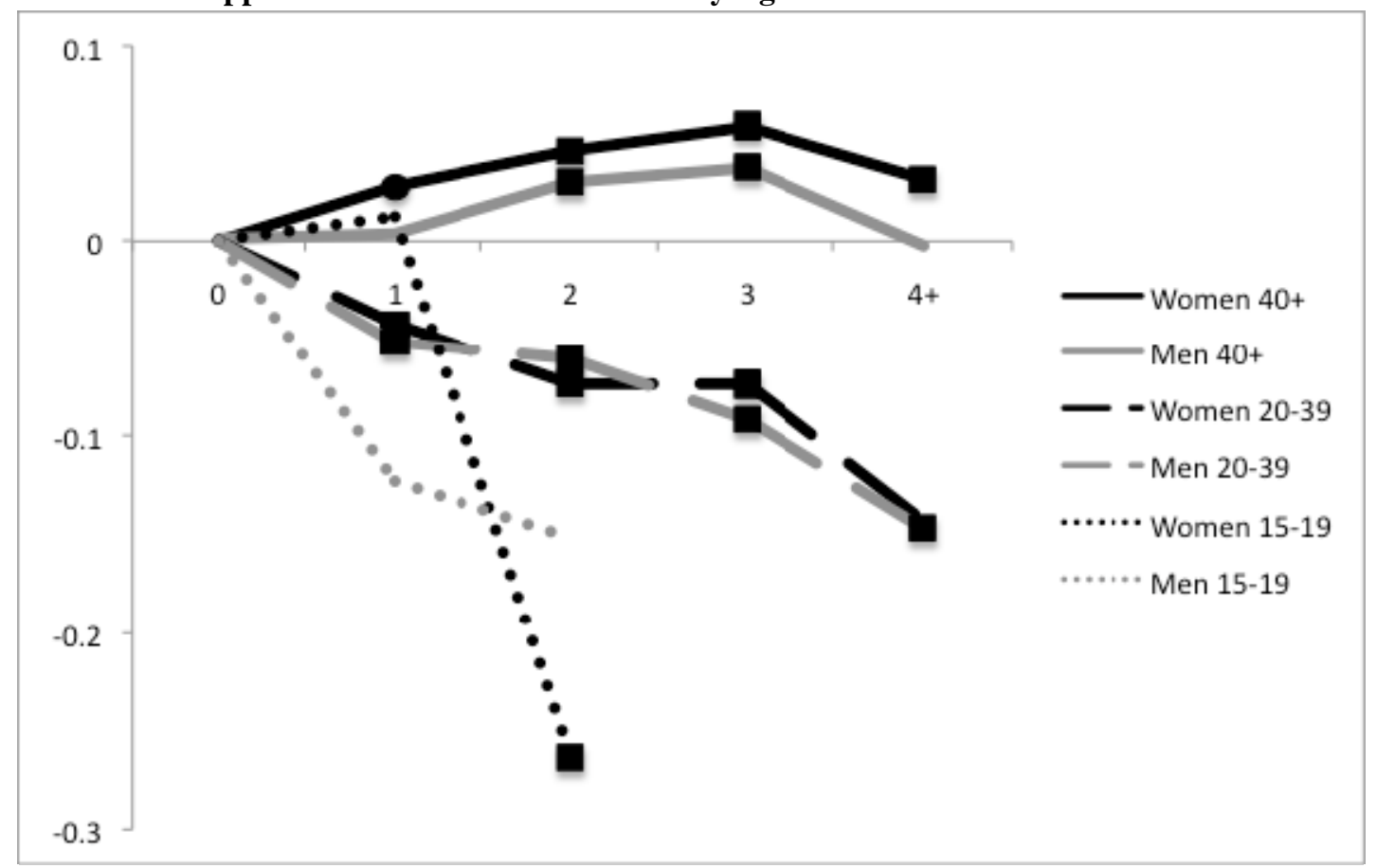

Notes: Lines connect coefficients from regression models predicting happiness (measured on a linear scale from 1 (not at all happy) to 4 (very happy) with number of children $(0,1,2,3,4+)$, controlling for sex, socioeconomic status, income, marital status, country, and year.

- $\mathrm{p}<.05 \bullet \mathrm{p}<.10$

SOURCE: World Values Surveys 1981-2005, N=201,988 
FIGURE 4 Happiness and Number of Children by Age and Partnership Status

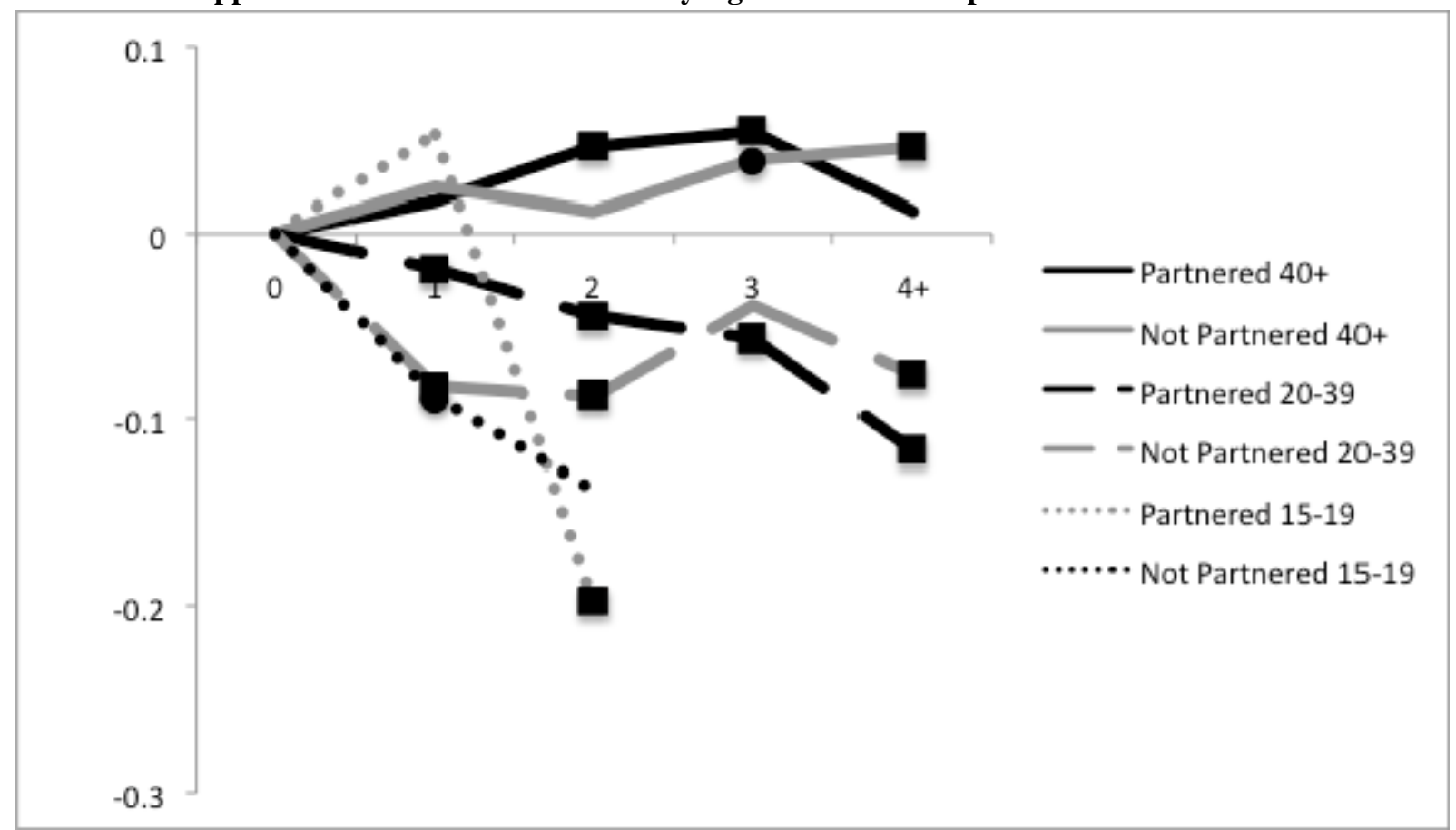

Notes: Lines connect coefficients from regression models predicting happiness (measured on a linear scale from 1 (not at all happy) to 4 (very happy) with number of children $(0,1,2,3,4+)$, controlling for sex, socioeconomic status, income, marital status, country, and year.

- $\mathrm{p}<.05 \bullet \mathrm{p}<.10$

SOURCE: World Values Surveys 1981-2005, N=201,988 
FIGURE 5a Happiness by Number of Children and Income Group, Ages 15-19

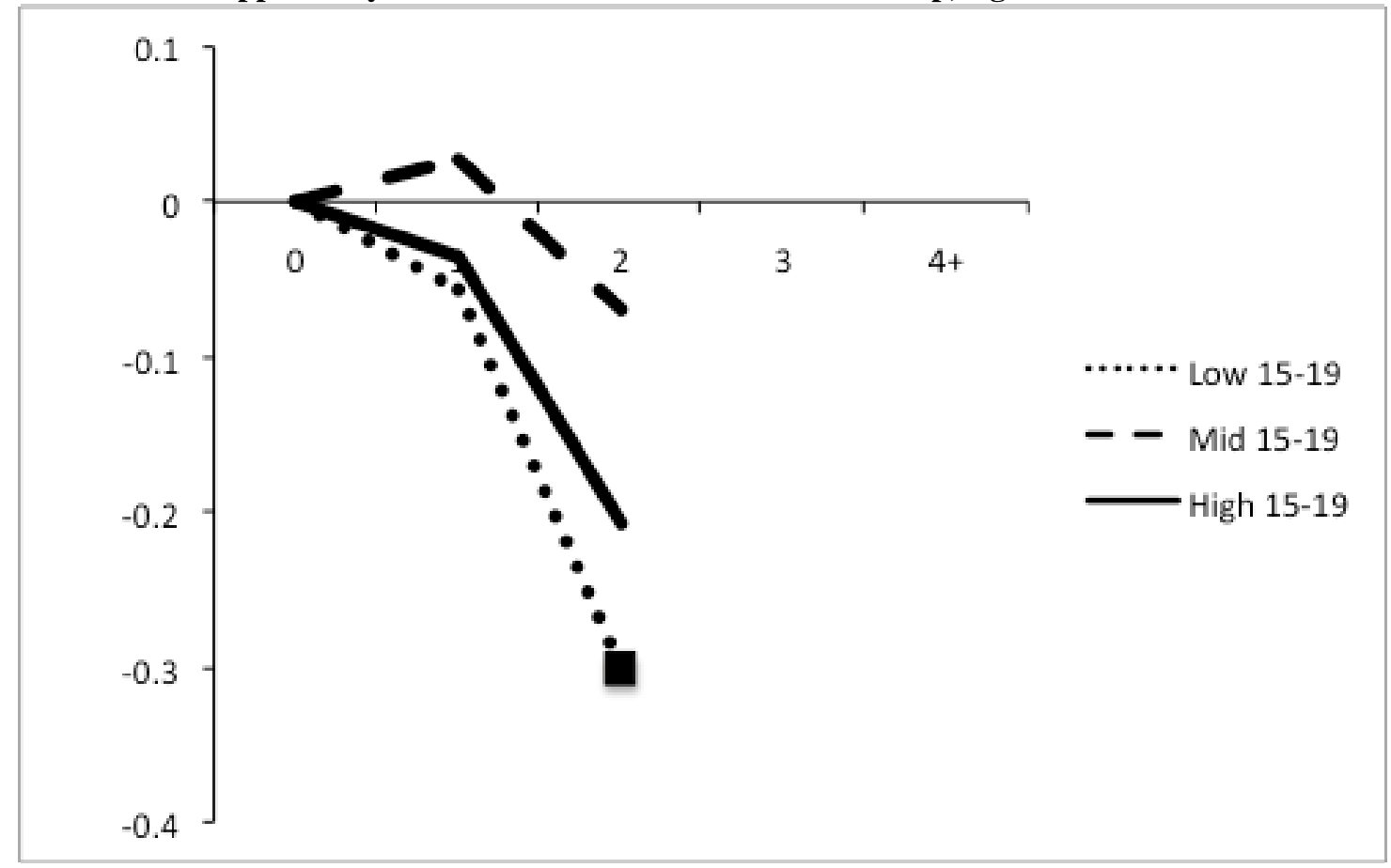

Notes: Lines connect coefficients from regression models predicting happiness (measured on a linear scale from 1 (not at all happy) to 4 (very happy) with number of children $(0,1,2,3,4+)$, controlling for sex, socioeconomic status, marital status, country, and year.

$\mathrm{p}<.05 \bullet \mathrm{p}<.10$

SOURCE: World Values Surveys 1981-2005, N=8,850 
FIGURE 5b. Happiness by Number of Children and Income Group, Ages 20-39

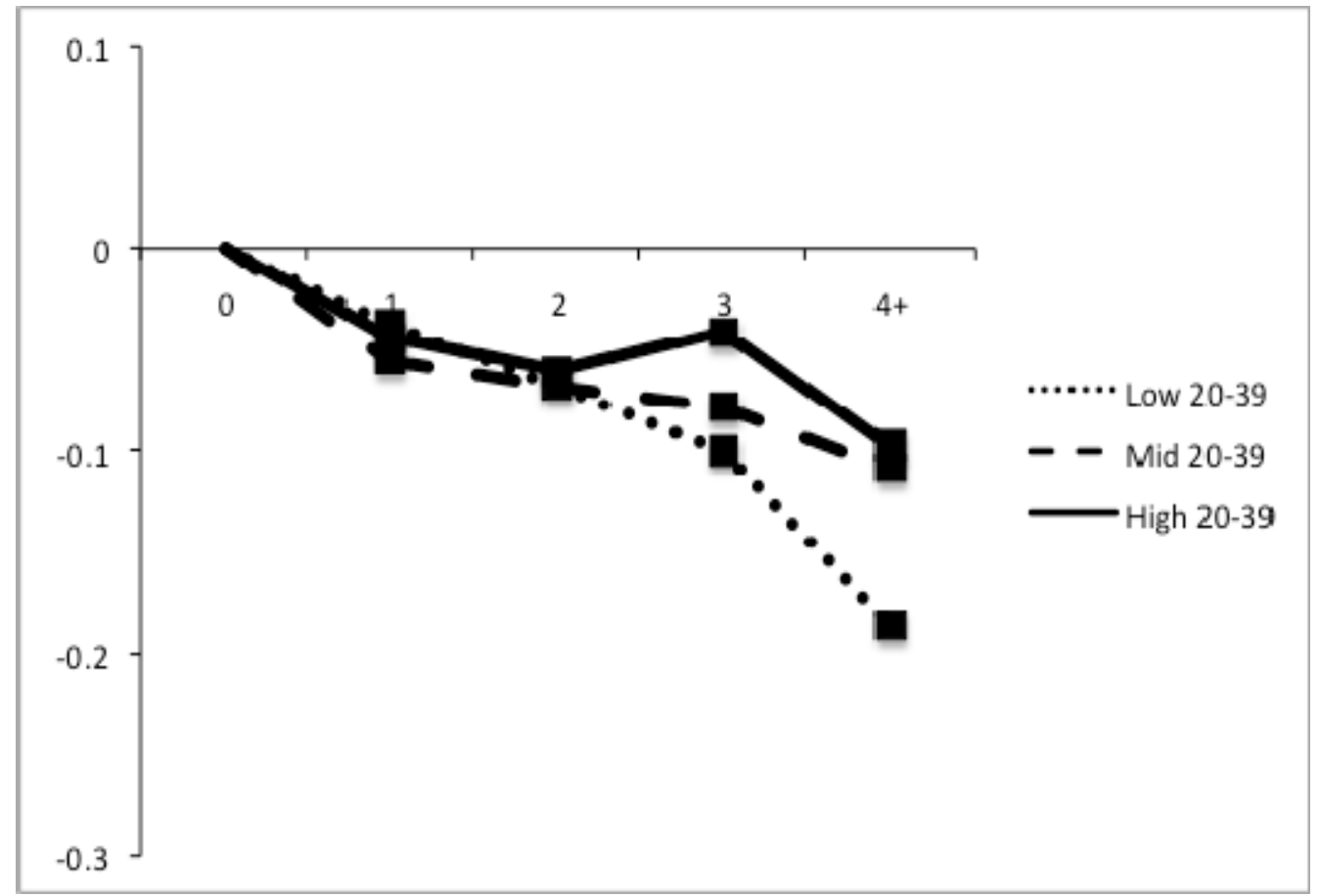

Notes: Lines connect coefficients from regression models predicting happiness (measured on a linear scale from 1 (not at all happy) to 4 (very happy) with number of children $(0,1,2,3,4+)$, controlling for sex, socioeconomic status, marital status, country, and year.

$\mathrm{p}<.05 \bullet \mathrm{p}<.10$

SOURCE: World Values Surveys 1981-2005, N=93,450 
FIGURE 5c Happiness by Number of Children and Income Group, Ages 40+

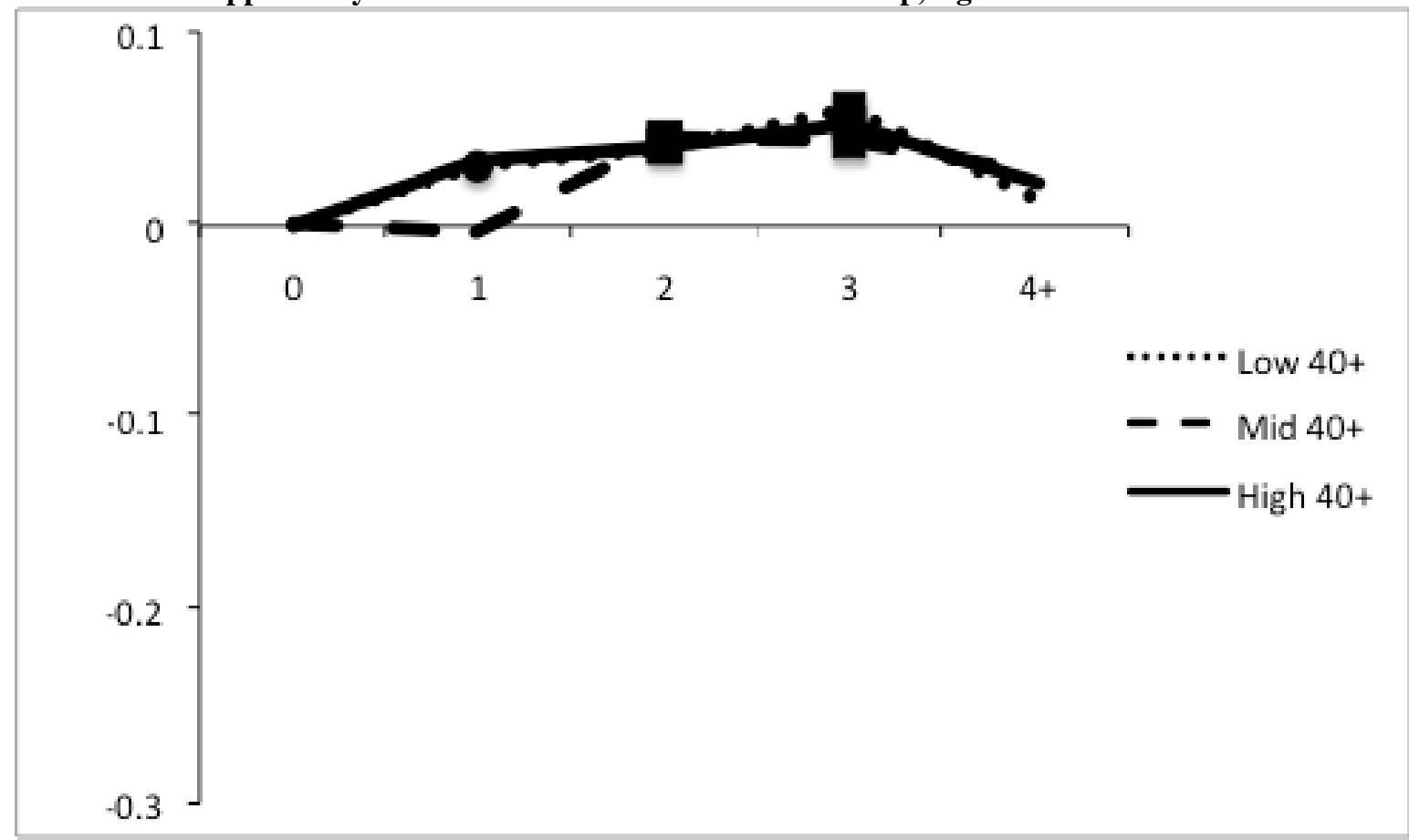

Notes: Lines connect coefficients from regression models predicting happiness (measured on a linear scale from 1 (not at all happy) to 4 (very happy) with number of children $(0,1,2,3,4+)$, controlling for sex, socioeconomic status, marital status, country, and year.

- $\mathrm{p}<.05 \bullet \mathrm{p}<.10$

SOURCE: World Values Surveys 1981-2005, N=99,688 
FIGURE 6 Happiness and Number of Children by Health Status

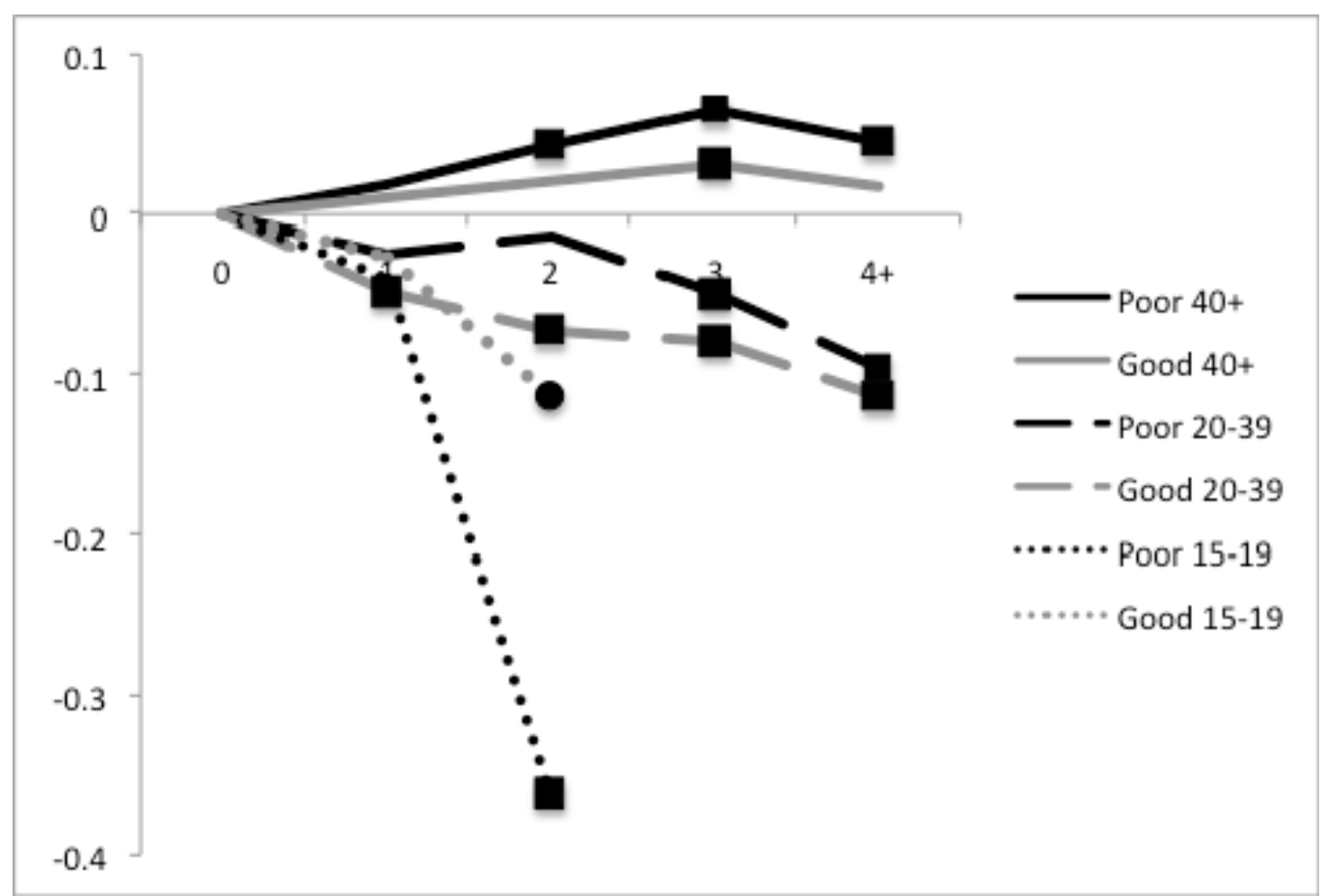

Notes: Lines connect coefficients from regression models predicting happiness (measured on a linear scale from 1 (not at all happy) to 4 (very happy) with number of children $(0,1,2,3,4+)$, controlling for sex, socioeconomic status, income, marital status, country, and year.

$\mathrm{p}<.05 \bullet \mathrm{p}<.10$

SOURCE: World Values Surveys 1981-2005, N=201,988 
FIGURE 7a Happiness and Number of Children by Welfare Regime, Ages 20-39

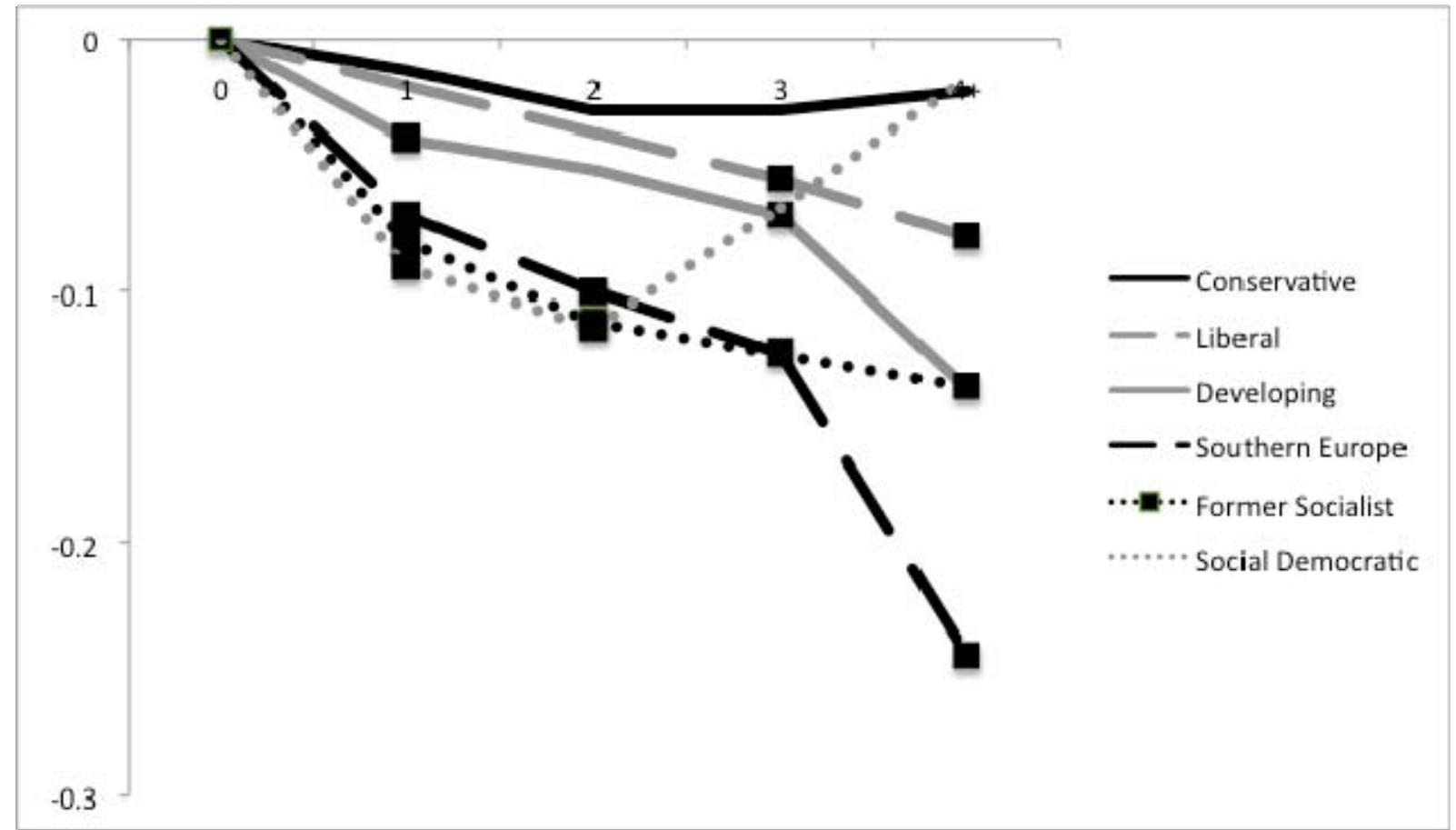

Notes: Lines connect coefficients from regression models predicting happiness (measured on a linear scale from 1 (not at all happy) to 4 (very happy) with number of children $(0,1,2,3,4+)$, controlling for sex, socioeconomic status, income, marital status, country, and year.

- $\mathrm{p}<.05 \bullet \mathrm{p}<.10$

SOURCE: World Values Surveys 1981-2005, N=93,450 
FIGURE 7b Happiness and Number of Children by Welfare Regime, Ages 40+

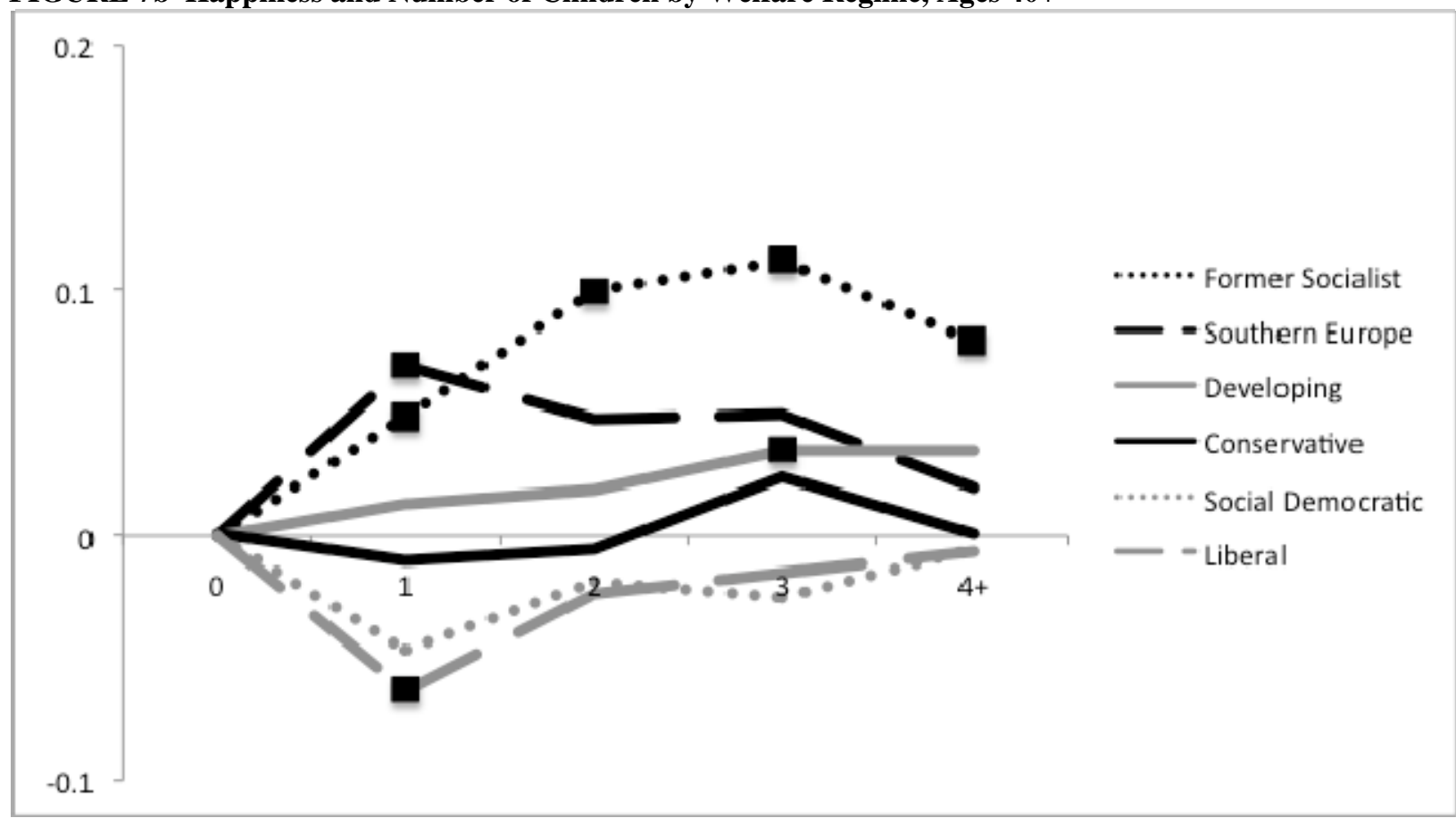

Notes: Lines connect coefficients from regression models predicting happiness (measured on a linear scale from 1 (not at all happy) to 4 (very happy) with number of children $(0,1,2,3,4+)$, controlling for sex, socioeconomic status, income, marital status, country, and year.

$\mathrm{p}<.05 \bullet \mathrm{p}<.10$

SOURCE: World Values Surveys 1981-2005, N=99,688 
FIGURE 8a Happiness and Fertility by Fertility Level, Ages 20-39

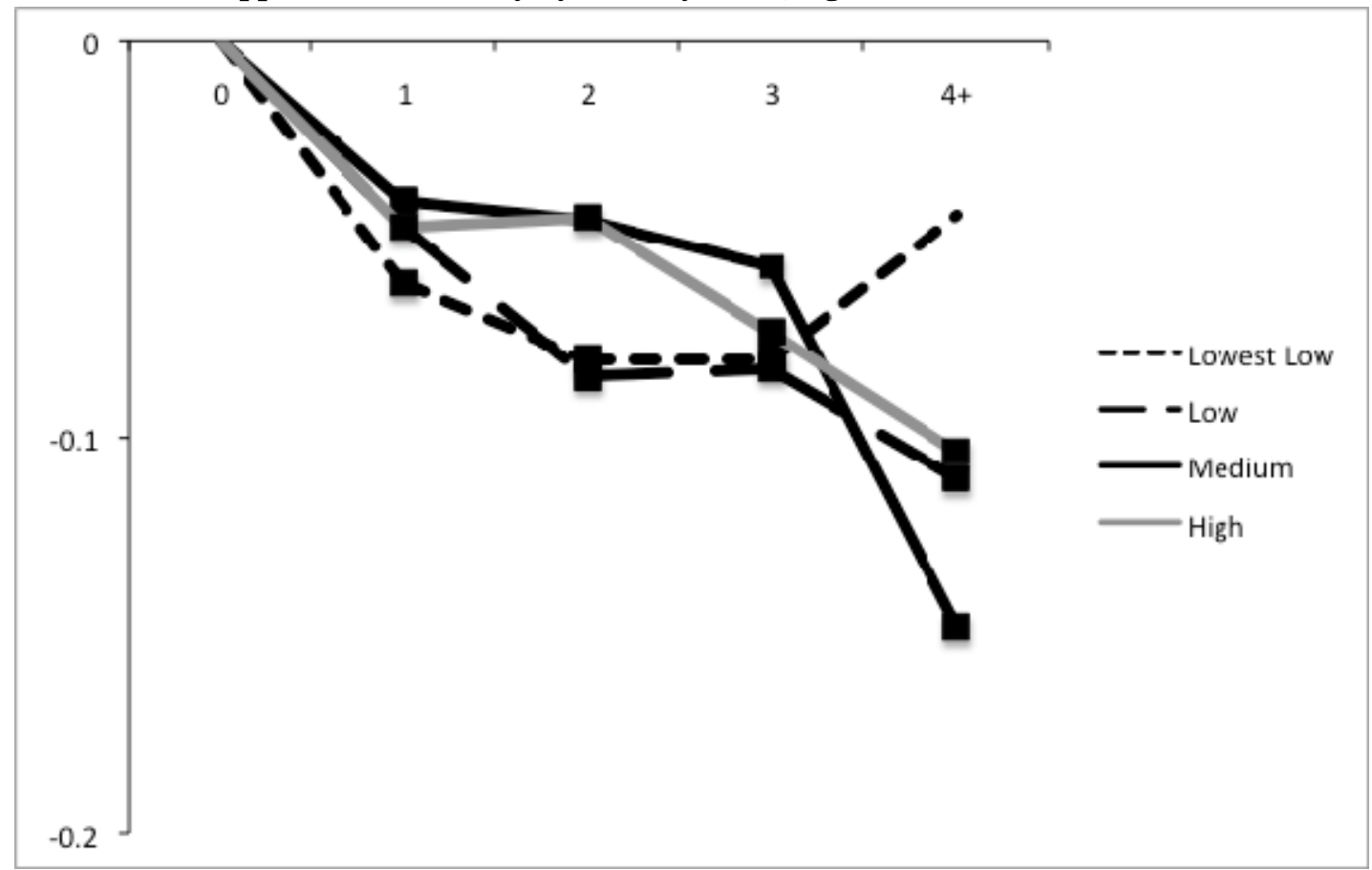

Notes: Lines connect coefficients from regression models predicting happiness (measured on a linear scale from 1 (not at all happy) to 4 (very happy) with number of children $(0,1,2,3,4+)$, controlling for sex, socioeconomic status, income, marital status, country, and year.

- $\mathrm{p}<.05 \bullet \mathrm{p}<.10$

SOURCE: World Values Surveys 1981-2005, N=93,450 
FIGURE 8b Happiness and Fertility by Fertility Level, Ages 40+

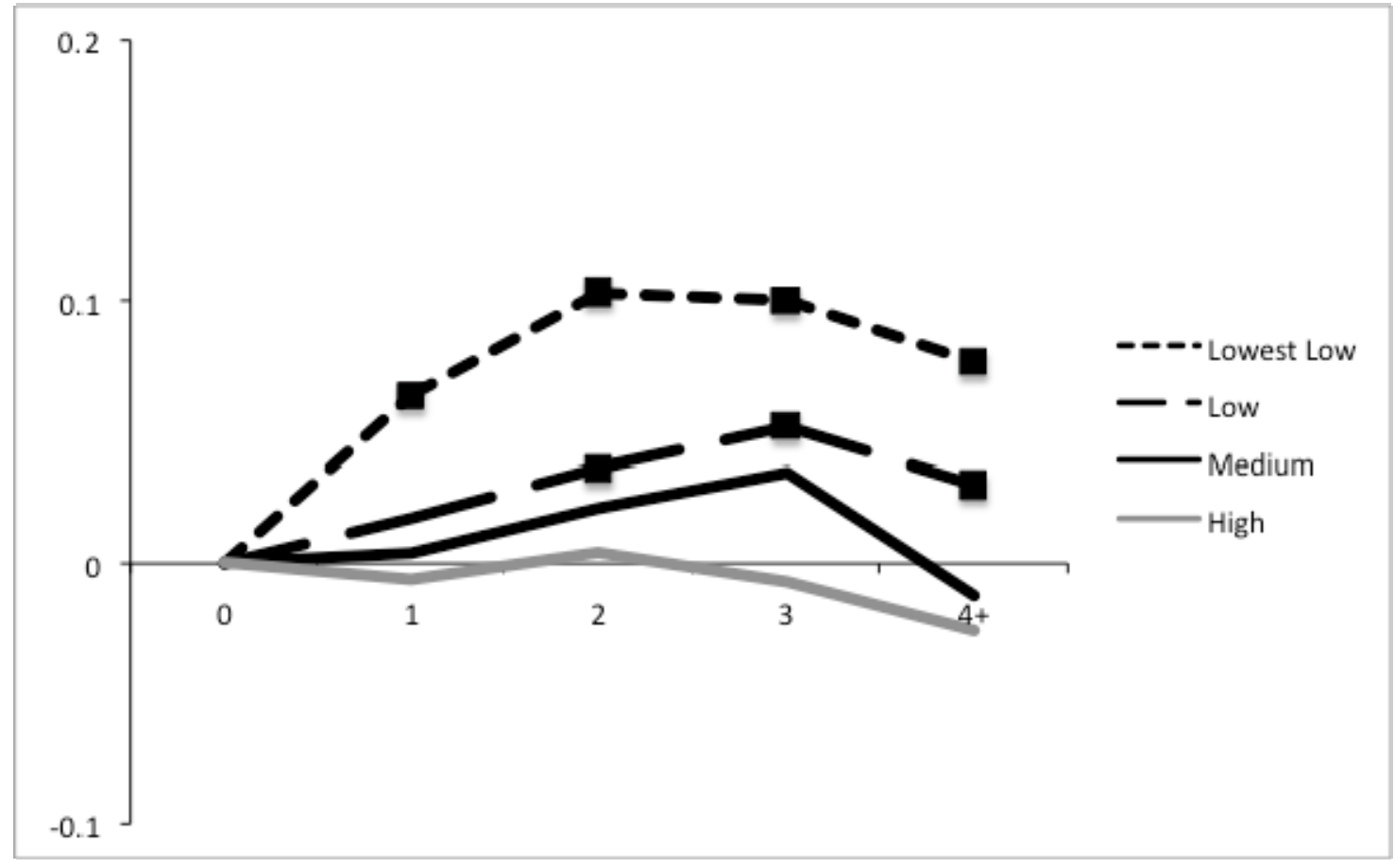

Notes:

Lines connect coefficients from regression models predicting happiness (measured on a linear scale from 1 (not at all happy) to 4 (very happy) with number of children $(0,1,2,3,4+)$, controlling for sex, socioeconomic status, income, marital status, country, and year.

$\mathrm{p}<.05 \bullet \mathrm{p}<.10$

SOURCE: World Values Surveys 1981-2005, N=99,688 
APPENDIX

TABLE A1 Welfare Regime Categorization

\begin{tabular}{|c|c|c|c|c|c|}
\hline $\begin{array}{l}\text { Social } \\
\text { Democratic }\end{array}$ & Conservative & $\begin{array}{l}\text { Southern } \\
\text { Europe }\end{array}$ & Liberal & $\begin{array}{l}\text { Former } \\
\text { Socialist }\end{array}$ & Developing \\
\hline $\begin{array}{l}\text { Denmark } \\
\text { Finland } \\
\text { Norway } \\
\text { Sweden } \\
\text { Netherlands }\end{array}$ & $\begin{array}{l}\text { Andorra } \\
\text { Austria } \\
\text { Belgium } \\
\text { France } \\
\text { Japan } \\
\text { Luxembourg } \\
\text { Switzerland } \\
\text { West Germany }\end{array}$ & $\begin{array}{l}\text { Portugal } \\
\text { Spain } \\
\text { Italy } \\
\text { Malta }\end{array}$ & $\begin{array}{l}\text { Australia } \\
\text { Canada } \\
\text { Ireland } \\
\text { New Zealand } \\
\text { Britain } \\
\text { USA }\end{array}$ & $\begin{array}{l}\text { Albania } \\
\text { Azerbaijan } \\
\text { Armenia } \\
\text { Bulgaria } \\
\text { Belarus } \\
\text { Croatia } \\
\text { Czech Republic } \\
\text { East Germany } \\
\text { Estonia } \\
\text { Georgia } \\
\text { Hungary } \\
\text { Kyrgyzstan } \\
\text { Latvia } \\
\text { Lithuania } \\
\text { Macedonia } \\
\text { Moldova } \\
\text { Poland } \\
\text { Romania } \\
\text { Russia } \\
\text { Slovakia } \\
\text { Slovenia } \\
\text { Ukraine } \\
\text { Macedonia }\end{array}$ & $\begin{array}{l}\text { Algeria } \\
\text { Argentina } \\
\text { Bangladesh } \\
\text { Brazil } \\
\text { Chile } \\
\text { China } \\
\text { Colombia } \\
\text { Cyprus } \\
\text { Dominican Republic } \\
\text { Egypt } \\
\text { El Salvador } \\
\text { Ethiopia } \\
\text { Ghana } \\
\text { India } \\
\text { Indonesia } \\
\text { Iran } \\
\text { Jordan } \\
\text { Malaysia } \\
\text { Mali } \\
\text { Mexico } \\
\text { Morocco } \\
\text { Nigeria } \\
\text { Pakistan } \\
\text { Peru } \\
\text { Philippines } \\
\text { Rwanda } \\
\text { Saudi Arabia } \\
\text { South Africa } \\
\text { South Korea } \\
\text { Taiwan } \\
\text { Tanzania } \\
\text { Thailand } \\
\text { Trinidad \& Tobago } \\
\text { Turkey } \\
\text { Uganda } \\
\text { Uruguay } \\
\text { Venezuela } \\
\text { Vietnam } \\
\text { Zambia } \\
\text { Zimbabwe } \\
\end{array}$ \\
\hline
\end{tabular}


TABLE A2 Total Fertility Rate by Country and Survey Year SOURCE: World Bank (2010)

\begin{tabular}{|c|c|c|c|c|c|c|c|c|}
\hline Country & Year & TFR & Country & Year & TFR & Country & Year & $\overline{T F R}$ \\
\hline Albania & 1998 & 2.40 & $\begin{array}{l}\text { Dominican } \\
\text { Repub. }\end{array}$ & 1996 & 3.08 & Malaysia & 2005 & 2.71 \\
\hline Albania & 2002 & 2.29 & East Germany & 1990 & 1.45 & Mali & 2005 & 6.59 \\
\hline Algeria & 2002 & 2.53 & East Germany & 197 & 1.05 & Malta & 1991 & 2.04 \\
\hline Andorra & 2005 & 1.31 & East Germany & 1999 & 1.17 & Malta & 1999 & 1.71 \\
\hline Argentina & 1991 & 2.93 & Egypt & 2000 & 3.43 & Mexico & 1990 & 3.31 \\
\hline Argentina & 1995 & 2.74 & Egypt & 2005 & 2.99 & Mexico & 1996 & 2.75 \\
\hline Argentina & 1999 & 2.52 & El Salvador & 1999 & 3.05 & Mexico & 2000 & 2.41 \\
\hline Armenia & 1997 & 1.75 & Estonia & 1996 & 1.33 & Mexico & 2005 & 2.20 \\
\hline Australia & 1995 & 1.82 & Ethiopia & 2005 & 5.57 & Moldova & 1996 & 1.67 \\
\hline Australia & 2005 & 1.79 & Finland & 1996 & 1.76 & Moldova & 2002 & 1.28 \\
\hline Austria & 1990 & 1.45 & Finland & 2005 & 1.80 & Moldova & 2005 & 1.50 \\
\hline Austria & 1999 & 1.34 & France & 1981 & 1.94 & Morocco & 2001 & 2.50 \\
\hline Azerbaijan & 1997 & 2.07 & France & 1990 & 1.78 & Morocco & 2005 & 2.43 \\
\hline Bangladesh & 1996 & 3.66 & France & 1999 & 1.79 & Netherlands & 1981 & 1.56 \\
\hline Bangladesh & 2002 & 3.00 & Georgia & 1996 & 1.65 & Netherlands & 1990 & 1.62 \\
\hline Belarus & 1996 & 1.31 & Ghana & 2005 & 4.4 & New Zealand & 1998 & 1.97 \\
\hline Belgium & 1981 & 1.67 & Hungary & 1991 & 1.86 & Nigeria & 1990 & 6.71 \\
\hline Belgium & 1990 & 1.62 & Hungary & 1999 & 1.29 & Nigeria & 1995 & 6.40 \\
\hline Belgium & 1999 & 1.61 & Iceland & 1984 & 2.08 & Nigeria & 2000 & 5.92 \\
\hline Brazil & 1991 & 2.70 & Iceland & 1990 & 2.31 & Norway & 1996 & 1.89 \\
\hline Brazil & 1997 & 2.45 & Iceland & 1999 & 1.99 & Pakistan & 1997 & 5.00 \\
\hline Brazil & 2005 & 2.04 & India & 1990 & 3.80 & Pakistan & 2001 & 4.59 \\
\hline Britain & 1981 & 1.81 & India & 1995 & 3.39 & Peru & 1996 & 3.30 \\
\hline Britain & 1990 & 1.83 & India & 2001 & 3.00 & Peru & 2001 & 2.93 \\
\hline Britain & 1998 & 1.71 & India & 2005 & 2.68 & Peru & 2005 & 2.67 \\
\hline Bulgaria & 1990 & 1.81 & Indonesia & 2001 & 2.39 & Philippines & 2001 & 3.52 \\
\hline Bulgaria & 1997 & 1.09 & Indonesia & 2005 & 2.26 & Poland & 1990 & 2.04 \\
\hline Bulgaria & 2005 & 1.31 & Iran & 2000 & 2.29 & Poland & 1997 & 1.51 \\
\hline Burkina Faso & 2005 & 6.15 & Ireland & 1981 & 3.07 & Poland & 1999 & 1.37 \\
\hline Canada & 1990 & 1.83 & Ireland & 1990 & 2.12 & Poland & 2005 & 1.24 \\
\hline Canada & 2000 & 1.49 & Italy & 1981 & 1.62 & Portugal & 1990 & 1.43 \\
\hline Chile & 1990 & 2.59 & Italy & 1990 & 1.26 & Romania & 1998 & 1.32 \\
\hline Chile & 1996 & 2.28 & Italy & 1999 & 1.23 & Romania & 2005 & 1.32 \\
\hline Chile & 2000 & 2.08 & Italy & 2005 & 1.32 & Russia & 1995 & 1.34 \\
\hline Chile & 2005 & 1.97 & Japan & 1990 & 1.54 & Rwanda & 2005 & 5.58 \\
\hline China & 1995 & 1.92 & Japan & 1995 & 1.42 & S. Africa & 1990 & 3.32 \\
\hline China & 2001 & 1.88 & Japan & 2000 & 1.36 & S. Africa & 1996 & 3.04 \\
\hline China & 2005 & 1.71 & Japan & 2005 & 1.26 & S. Africa & 2001 & 2.86 \\
\hline Colombia & 1998 & 2.77 & Jordan & 2001 & 3.69 & S. Africa & 2005 & 2.78 \\
\hline Croatia & 1996 & 1.67 & Kyrgyzstan & 2003 & 2.50 & S. Korea & 1996 & 1.58 \\
\hline Croatia & 1999 & 1.38 & Latvia & 1996 & 1.16 & S. Korea & 2005 & 1.08 \\
\hline Cyprus & 2005 & 1.42 & Latvia & 1999 & 1.16 & Saudi Arabia & 2003 & 4.09 \\
\hline Czech Republic & 1991 & 1.86 & Lithuania & 1997 & 1.47 & Slovakia & 1991 & 2.05 \\
\hline Czech Republic & 1998 & 1.16 & Luxembourg & 1999 & 1.73 & Slovakia & 1998 & 1.38 \\
\hline Czech Republic & 1999 & 1.13 & Macedonia & 1998 & 1.90 & Slovakia & 1999 & 1.33 \\
\hline Denmark & 1981 & 1.43 & Macedonia & 2001 & 1.75 & Slovenia & 1992 & 1.34 \\
\hline
\end{tabular}


TABLE A2 CONTINUED

\begin{tabular}{lllllllll}
\hline Country & Year & TFR & Country & Year & TFR & Country & Year & TFR \\
\hline Slovenia & 2005 & 1.26 & Taiwan & 2005 & 1.11 & USA & 1999 & 2.01 \\
Spain & 1981 & 2.03 & Tanzania & 2001 & 5.62 & Uruguay & 1996 & 2.5 \\
Spain & 1990 & 1.33 & Thailand & 2005 & 1.81 & Venezuela & 1996 & 3.04 \\
Spain & 1995 & 1.18 & Trinidad \& & 2005 & 1.62 & Venezuela & 2000 & 2.83 \\
& & & Tobago & & & & & \\
Spain & 1999 & 1.20 & Turkey & 1990 & 3.00 & Vietnam & 2001 & 1.88 \\
Spain & 2000 & 1.24 & Turkey & 1996 & 2.76 & Vietnam & 2005 & 2.21 \\
Spain & 2005 & 1.35 & Turkey & 2001 & 2.52 & West Germany & 1981 & 1.43 \\
Sweden & 1996 & 1.60 & Turkey & 2005 & 2.17 & West Germany & 1990 & 1.45 \\
Sweden & 1999 & 1.50 & Uganda & 2001 & 6.9 & West Germany & 1997 & 1,39 \\
Sweden & 2005 & 1.77 & Ukraine & 1996 & 1.30 & West Germany & 1999 & 1.39 \\
Switzerland & 1996 & 1.50 & Ukraine & 2005 & 1.20 & Zambia & 2005 & 5.96 \\
Switzerland & 2005 & 1.42 & USA & 1990 & 2.08 & Zimbabwe & 2001 & 3.66 \\
Taiwan & 1994 & 1.75 & USA & 1995 & 1.98 & & & \\
\hline Czech Republic & 1991 & 1.86 & Lithuania & 1997 & 1.47 & Slovakia & 1991 & 2.05 \\
Czech Republic & 1998 & 1.16 & Luxembourg & 1999 & 1.73 & Slovakia & 1998 & 1.38 \\
Czech Republic & 1999 & 1.13 & Macedonia & 1998 & 1.90 & Slovakia & 1999 & 1.33 \\
Denmark & 1981 & 1.43 & Macedonia & 2001 & 1.75 & Slovenia & 1992 & 1.34
\end{tabular}

